\title{
Coordination behavior of benzimidazole, 2-substituted benzimidazoles and benzothiazoles, towards transition metal ions
}

\author{
Fabiola Téllez, Horacio López-Sandoval, Silvia E. Castillo-Blum, and \\ Noráh Barba-Behrens* \\ Departamento de Química Inorgánica, Facultad de Química, UNAM, Av. Universidad 3000, \\ C.U., Coyoacán, México, D.F., 04510, México \\ E-mail:norah@servidor.unam.mx
}

\section{Dedicated to Rosalinda Contreras, friend and colleague, in recognition of her contribution to coordination chemistry}

\begin{abstract}
Coordination chemistry of benzimidazole and 2-substituted benzimidazole derivatives towards transition metal ions is reviewed. Benzimidazole complexes containing halides or carboxylates derivatives are discussed, as well as the coordination chemistry of 2-substituted benzimidazoles bearing additional nitrogen, oxygen or sulfur atoms as potential binding sites, which may form chelates. The latter ligands give place to a variety of metal-ligand coordination modes. In some cases, these bidentate ligands favour the formation of a six membered ring, by inclusion of a metal ion in a planar delocalized system. Some of the studied 2-substituded benzimidazoles include 2-uroyl, 2-carbamate, 2-benzothiazole, 2-(2-benzothiazolylamino)benzothiazole, 2-(2aminobenzothiazolyl-amino) benzoxazole, 2-(4'-thiazolyl)benzimidazole, 2-((5-methylpyrazol-3yl)methyl)benzimidazole, 2-guanidinobenzimidazole, 2-aminomethylbenzimidazole, 1(benzimidazol-2-yl)phenolato, 2-(2-benzimidazol-2-yl)pyridine- $N$-oxide- $N, O \quad$ and $\quad N$ (benzothiazol-2-yl)-dithiocarbamic methyl ester. It is important to mention that benzimidazole and its derivatives promote intra and inter-molecular interactions, such as hydrogen bonding and $\pi$ - stacking, giving place to the formation of molecular aggregates.
\end{abstract}

Keywords: Benzimidazole, benzothiazole, transition metal, coordination compounds 


\section{Table of contents}

1. Introduction

2. Benzimidazole

2.1. Benzimidazole coordination compounds

2.1.1. Halide compounds

2.1.2. Carboxylate derivatives compounds

3. 2-Substituted Benzimidazoles

3.1. Nitrogen monodentate compounds

3.1.1. 2-uroyl, 2-carbamate and 2-benzothiazole coordination compounds

3.2. $\quad(\mathrm{N}, \mathrm{N}) ;(\mathrm{N}, \mathrm{O}) ;(\mathrm{N}, \mathrm{S})$; chelate compounds

3.2.1. (N, N) coordination compounds

3.2.1.1. 2-(2-benzothiazolylamino)benzothiazole and 2-(2-aminobenzothiazolyl-amino) benzoxazole

3.2.1.2. 2-(4'-thiazolyl)benzimidazole

3.2.1.3. 2-((5-methylpyrazol-3-yl)methyl)benzimidazole

3.2.1.4. 2-guanidinobenzimidazole

3.2.1.5. 2-aminomethylbenzimidazole

3.2.1.6. 2-(2-pyridyl)-benzimidazole

3.2.1.7. 2-(2-benzimidazolyl-6- $R$ )-4,4,5,5-tetramethyl-4,5-dihydro-1H-imidazolyl-3-oxide$1-$ oxy

3.2.2. ( $\mathrm{N}, \mathrm{O})$ coordination compounds

3.2.2.1. 1-(benzimidazol-2-yl)phenolato

3.2.2.2. 2-(2-benzimidazol-2-yl)pyridine-N-oxide-N,O

3.2.3. (N, S) coordination compounds

3.2.3.1 N-(benzothiazol-2-yl)-dithiocarbamic methyl ester

4. Concluding Remarks

5. References

\section{Introduction}

Benzimidazoles are involved in a great variety of biological processes. Some of their polyfunctional derivatives have been proved to possess antibacterial, fungicide and antihelmintic activity. ${ }^{1-13 a}$ Therefore, substituted benzimidazoles have attracted the interest of various research groups, especially since it has been reported that the influence of the substitution at the 1,2 and 5 positions of the benzimidazole ring is very important for their pharmacological effects. ${ }^{13 \mathrm{~b}}$ Nevertheless, the research concerned with the biological activity of coordination compounds containing benzimidazole derivatives has been limited. ${ }^{14-17}$ 
The biological activity and pharmacological properties of the benzimidazole derivatives, have led us to investigate the coordination behavior of benzimidazole and benzothiazole derivatives towards transition metal ions. Herein, a number of coordination compounds with manganese(II), cobalt(II), nickel(II), copper(II), zinc(II), cadmium(II), mercury(II), chromium(III) and cobalt(III) and polyfunctional benzazole derivatives are discussed. These polyfunctional molecules bear nitrogen, oxygen and sulfur atoms as basic sites for coordination. Bonding occurs through the nitrogen atom in a monodentate form, regardless of the metal ion or the heteroatom $(\mathrm{N}, \mathrm{S}, \mathrm{O})$ present in the molecule, or in a bidentate mode, giving place to a variety of metal-ligand coordination modes. In some cases, the formation of a six membered ring by inclusion of a metal ion in a planar delocalized system is observed, where the ligand is bonded in a bidentate mode.

\section{Benzimidazole}

\subsection{Benzimidazole coordination compounds}

\subsubsection{Halide compounds}

Several groups have reported cobalt(II) and zinc(II) coordination compounds showing a similar stoichiometry $\left[\mathrm{M}(\mathrm{bz})_{2} \mathrm{X}_{2}\right]\left(\mathrm{M}^{\mathrm{II}}=\mathrm{Co}, \mathrm{Zn} ; \mathrm{X}^{-}=\mathrm{Cl}, \mathrm{Br}, \mathrm{I}\right) .{ }^{18 \mathrm{a}-18 \mathrm{c}}$ In all cases, the geometry adopted by the metal ion is tetrahedral. The compound dichloro-bis(1H-benzimidazole)-cobalt(II), reported Barba-Behrens et. al., is an example is of this type of complexes, where the two chlorine ions $\left(\mathrm{Cl}^{-}\right)$and two benzimidazoles are bonded to the metal center through the unprotonated nitrogen, Figure 1. ${ }^{18 \mathrm{a}}$

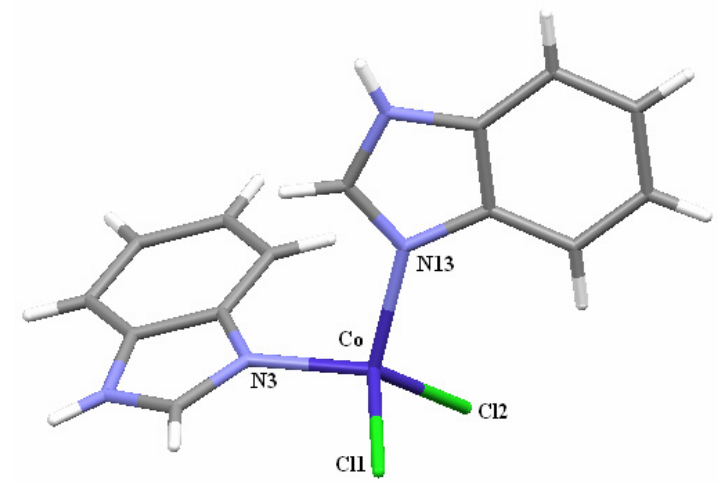

Figure 1. Dichloro-bis( $1 H$-benzimidazole)-cobalt(II). ${ }^{18 a}$

The copper(II) halide complexes, present a different behavior from that of the $\mathrm{Co}^{\mathrm{II}}$ or $\mathrm{Zn}^{\mathrm{II}}$ compounds, where the metal ion stabilizes different geometries. In the case of the $\left[\mathrm{Cu}(\mathrm{bz}){ }_{2} \mathrm{Br}_{2}\right]$ compound, the $\mathrm{Cu}^{\mathrm{II}}$ ion adopted a trans-square planar geometry, to minimize the steric hindrance of the benzimidazole molecules. ${ }^{19}$ 


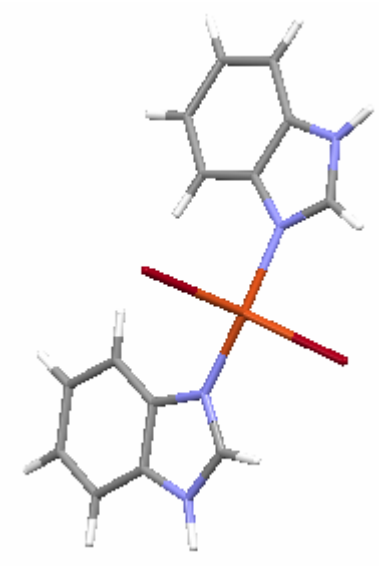

Figure 2. $\left[\mathrm{Cu}(\mathrm{bz})_{2} \mathrm{Br}_{2}\right]$, where copper(II) is in a square planar geometry. ${ }^{19}$

Two dinuclear compounds $\left[\mathrm{Cu}_{2}(\mathrm{bz})_{5} \mathrm{Br}_{3}\right] \mathrm{Br} \cdot 4 \mathrm{H}_{2} \mathrm{O}$ and $\left[\mathrm{Cu}_{2}(\mathrm{Bz})_{5} \mathrm{Cl}_{3}\right] \mathrm{Cl} \cdot 4 \mathrm{H}_{2} \mathrm{O}$ were reported by Tosik et. al. These compounds are isostructural and consist of pairs of copper(II) ions in a distorted trigonal bipyramid geometry sharing an edge with two equatorial halide ions, the axial positions are occupied by the nitrogen atoms from four benzimidazole ligands, Figure 3. The $\mathrm{Cu}^{\cdots} \mathrm{Cu}$ distance in $\left[\mathrm{Cu}_{2}(\mathrm{Bz})_{5} \mathrm{Cl}_{3}\right] \mathrm{Cl} \cdot 4 \mathrm{H}_{2} \mathrm{O}$ is $3.386(1) \AA$, while in $\left[\mathrm{Cu}_{2}(\mathrm{Bz})_{5} \mathrm{Br}_{3}\right] \mathrm{Br}^{-} \cdot 4 \mathrm{H}_{2} \mathrm{O}$ is 3.4894(7) $\AA$, allowing ferromagnetic coupling between the metal ions $\left(J^{\prime}=-0.6 \mathrm{~cm}^{-1}\right.$ and $2 J=$ $\left.5.6 \mathrm{~cm}^{-1}\right) .{ }^{20 \mathrm{a}, 20 \mathrm{~b}}$

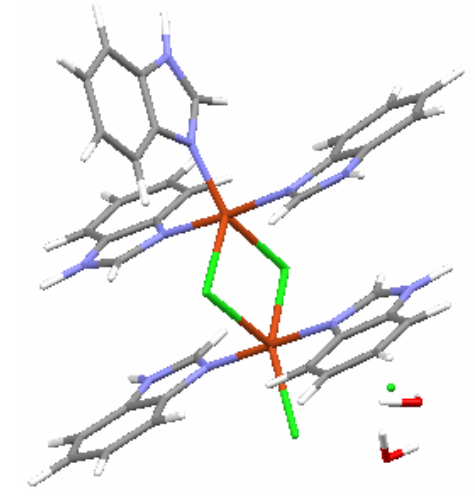

a

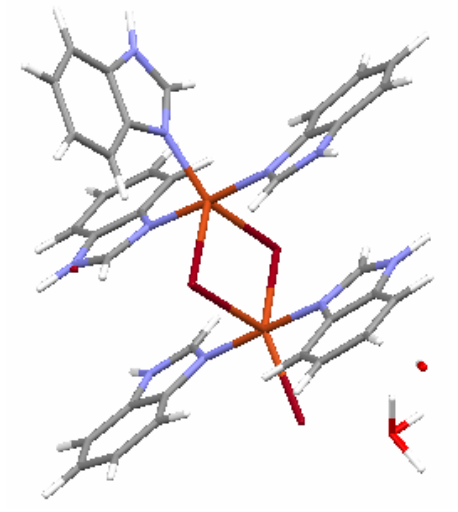

b

Figure 3. Copper(II) dinuclear compounds: a) $\left[\mathrm{Cu}_{2}\left(\mathrm{Bz}_{5} \mathrm{Cl}_{3}\right] \mathrm{Cl} \cdot 4 \mathrm{H}_{2} \mathrm{O} ; \quad\right.$ b) $\left[\mathrm{Cu}_{2}(\mathrm{Bz})_{5} \mathrm{Br} 3\right] \mathrm{Br} \cdot 4 \mathrm{H}_{2} \mathrm{O} .^{20 \mathrm{a}, 20 \mathrm{~b}}$

The tetranuclear copper(II) complex $\left[\mathrm{Cu}_{4} \mathrm{Cl}_{6} \mathrm{O}(\mathrm{bz})_{4}\right] \cdot 2 \mathrm{C}_{2} \mathrm{H}_{5} \mathrm{OH}$ was first reported by Tosik and later by $\mathrm{Xu}^{21 \mathrm{a},}{ }^{21 \mathrm{~b}}$ In this compound, each metal ion is in a distorted trigonal bipyramid geometry bonded to three equatorial chloride atoms, one benzimidazole in an axial position, and the fifth position is occupied by the central oxygen atom O1, Figure 4 . The analogous structure with imidazole and copper(II) was obtained by Barba-Behrens and co-workers. ${ }^{22}$ 


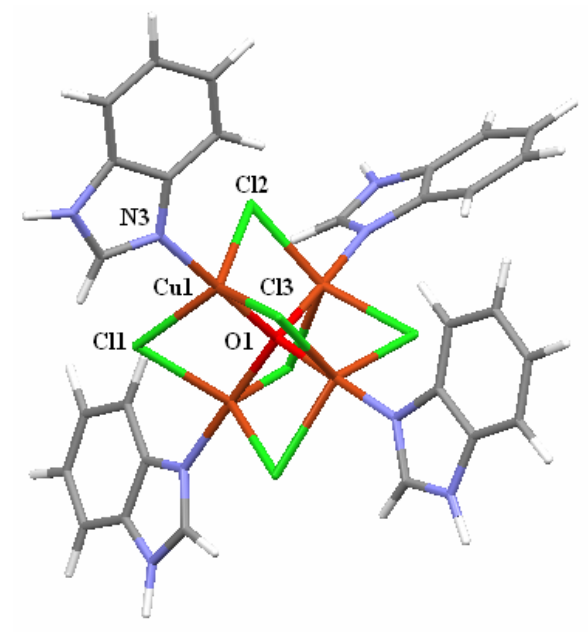

Figure 4. Copper(II) tetranuclear compound $\left[\mathrm{Cu}_{4} \mathrm{Cl} \mathrm{C}_{6} \mathrm{O}(\mathrm{bz})_{4}\right] \cdot 2 \mathrm{C}_{2} \mathrm{H}_{5} \mathrm{OH} .{ }^{21 \mathrm{a}, 21 \mathrm{~b}}$

\subsubsection{Carboxylate derivatives compounds}

In the past years, it has been of great interest to study the coordination behavior of benzimidazole compounds with a variety of carboxylate derivatives.

The research groups of $\mathrm{Xu}$ and Bukowska-Strzyzewska have investigated the chemistry of cobalt(II), nickel(II) and copper(II) coordination compounds containing benzimidazole and carboxylic acids derivatives, as described below. The compounds resulted monomeric, dimeric or polymeric complexes, the number of coordinated benzimidazole molecules to the metal ion varies and also different geometries are stabilized.

$\mathrm{Xu}$ et. al. reported the synthesis of monomeric and polymeric coordination compounds with cobalt(II) chloride and malonic acid. In the monomeric compound, the metal ion presented an octahedral geometry with four benzimidazole ligands and one bidentate malonate dianion. ${ }^{23 a}$ In the polymeric compound catena- $\left(\left(\mu_{2}\right.\right.$-malonato $)$-aqua- $(1 H$-benzimidazole $)$ cobalt(II)), the polymeric array was stabilized through the carboxylic groups, where the malonate ligand forms a six-membered chelate, bridging two metal ions, which are in an octahedral geometry, Figure $5 \mathrm{a} .{ }^{23 b}$ Another example of these compounds is the analogous copper(II) compound, Figure 5b, where the copper(II) atom stabilizes a square-pyramidal geometry. ${ }^{23 \mathrm{c}}$ In these two compounds, one benzimidazole ligand is coordinated to the metal atoms. 


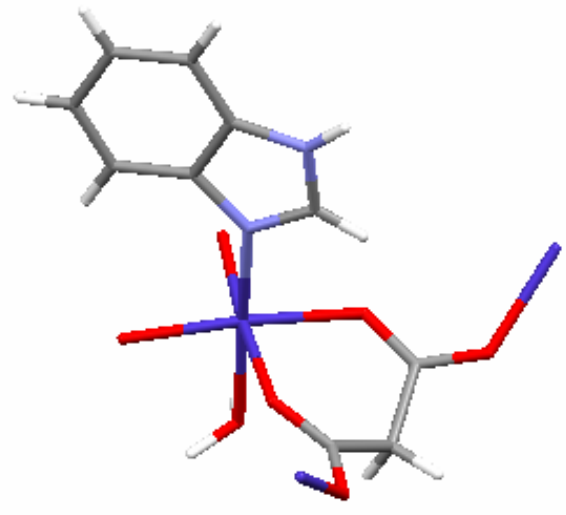

a

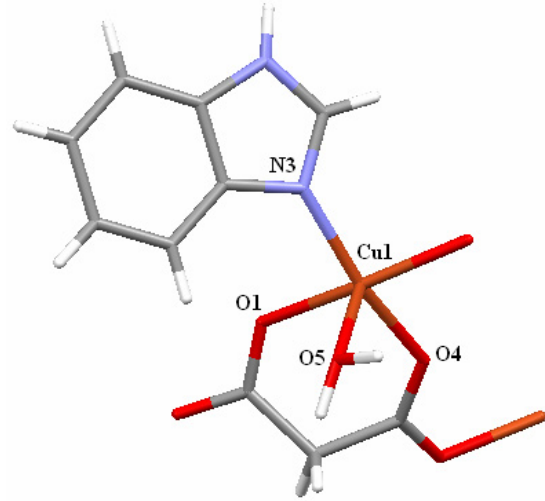

b

Figure 5. (a) Catena-(( $\mu_{2}$-malonato)-aqua-(1H-benzimidazole $)$ cobalt(II)); (b) catena- $\left(\left(\mu_{2}\right.\right.$ malonato)-aqua-(1H-benzimidazole)copper(II)). ${ }^{23 \mathrm{~b}, 23 \mathrm{c}}$

In the polymeric maleate coordination compounds, catena- $\left(\left(\mu_{2}\right.\right.$-maleato, $\left.O, O^{\prime}, O^{\prime \prime}\right)$-tris $(1 \mathrm{H}-$ benzimidazole)-M(II)) $(\mathrm{M}(\mathrm{II})=\mathrm{Co}$ or $\mathrm{Ni})$, Figure 6 , three benzimidazole ligands and two maleate dianions are coordinated to the $\mathrm{M}$ (II) atoms, in a distorted octahedral geometry, where the mer-isomer is stabilized, minimizing the steric crowding around the metal ion. Maleate dianions bridge neighboring $\mathrm{M}(\mathrm{II})$ atoms through terminal carboxyl groups, one in monodentate and the other in chelate mode, to form polymeric right handed molecular chains, extending along the $a$ axis. These compounds are chiral. Intra- and intermolecular hydrogen bonding and $\pi-\pi$ stacking stabilizes the crystal structure. ${ }^{24 a, 24 b}$

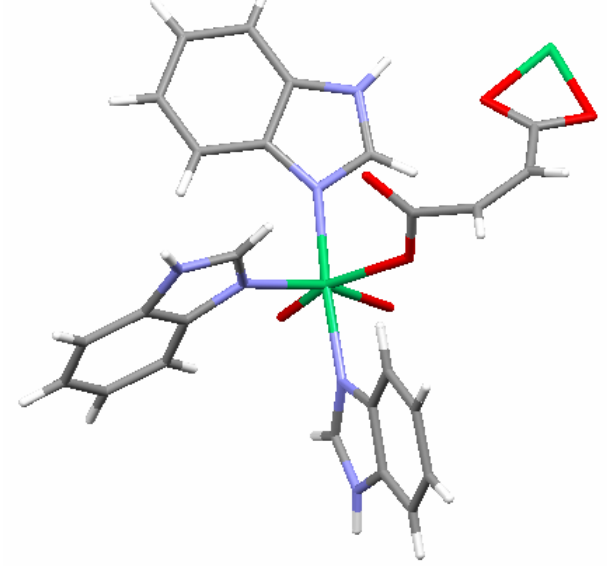

a

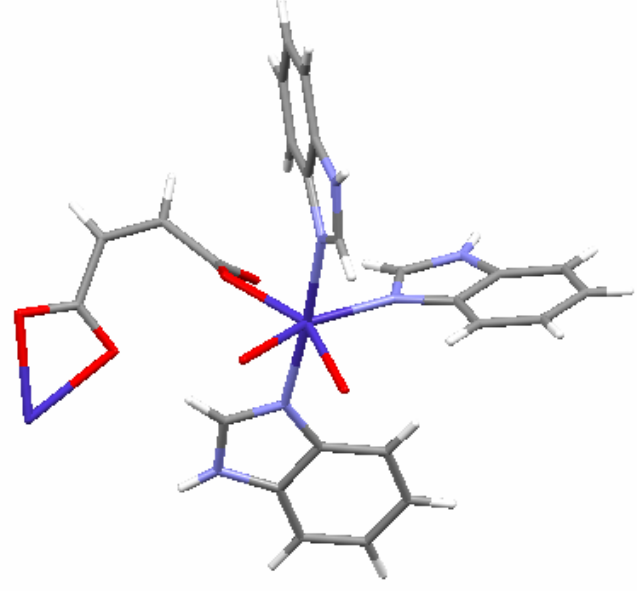

b

Figure 6. (a) Catena-(( $\mu_{2}$-maleato, $\left.O, O^{\prime}, O^{\prime \prime}\right)$-tris $(1 H$-benzimidazole $)$-cobalt(II)); b) catena- $\left(\left(\mu_{2}\right.\right.$ maleato $\left.O, O^{\prime}, O^{\prime \prime}\right)$-tris( $1 H$-benzimidazole)-nickel(II)). ${ }^{24 \mathrm{a}, 24 \mathrm{~b}}$ 
Compounds with fumaric and succinic acid, catena- $\left(\left(\mu_{2}\right.\right.$-fumarato- $\left.O, O^{\prime}\right)$-diaqua-bis $(1 H$ benzimidazole-N)-M(II)) (M(II) = cobalt, ${ }^{25 \mathrm{a}}$ nickel, ${ }^{25 \mathrm{~b}}$ copper $\left.{ }^{25 \mathrm{c}}\right)$, and catena- $\left(\left(\mu_{2}\right.\right.$-succinato$\left.O, O^{\prime}\right)$-diaqua-bis $\left(1 H\right.$-benzimidazole-N)-M(II)) $\left(\mathrm{M}(\mathrm{II})=\right.$ cobalt,${ }^{25 \mathrm{a}}$ and copper $\left.{ }^{25 \mathrm{c}}\right)$, were obtained from the corresponding acid in alkaline medium. These compounds consist of a polymeric $\mathrm{M}^{\mathrm{II}}$ complex bridged by fumarato or succinato dianions, each carboxyl group is bonded in a monodentate mode to the metal atom and it is also bonded to a neighboring metal ion through terminal carboxyl groups forming one-dimensional polymeric chains, Figure 7. Adjacent chains are linked via $\mathrm{N}-\mathrm{H}^{\cdots \cdots} \mathrm{O}$ hydrogen bonds between benzimidazole and carboxylic groups, as by $\mathrm{O}-$ $\mathrm{H}^{\cdots \cdots} \mathrm{O}$ hydrogen bonds between coordinated water molecules and carboxyl groups. A similar copper(II) compound with acetylendicarboxylato was reported by Sieron et. al. ${ }^{25 c}$

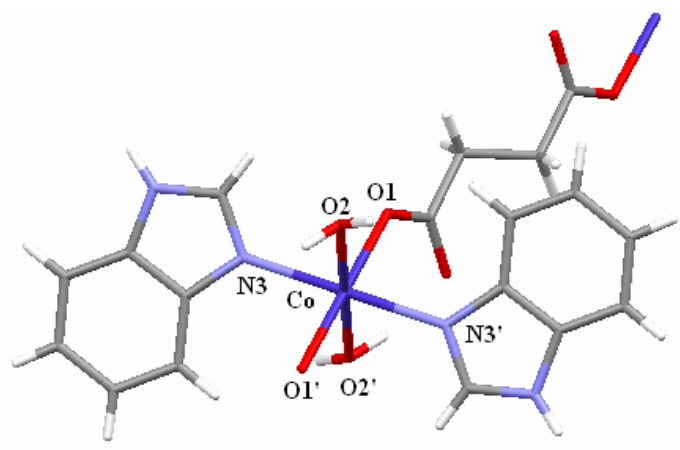

Figure 7. Catena-(( $\mu_{2}$-succinato- $\left.O, O^{\prime}\right)$-diaqua-bis $\left(1 H\right.$-benzimidazole-N)-cobalt(II)). ${ }^{25 \mathrm{~d}}$

The syntheses of the cobalt(II) coordination compounds with terephthalic and isoterephthalic, catena- $\left(\left(\mu_{2}\right.\right.$-terephthalato $)$-bis $(1 \mathrm{H}$-benzimidazole $)$-cobalt(II)) and catena- $\left(\left(\mu_{2}\right.\right.$-isoterephthalato)-bis(1H-benzimidazole)-cobalt(II)), were carried out under similar conditions to those of the previous complexes. In the latter compound, cobalt(II) has a distorted geometry; with two benzimidazole ligands and one carboxyl group coordinated in a monodentate manner, while another carboxyl group forms polymeric complex chains, Figure $8 .{ }^{26 a}, 26 \mathrm{~b}$

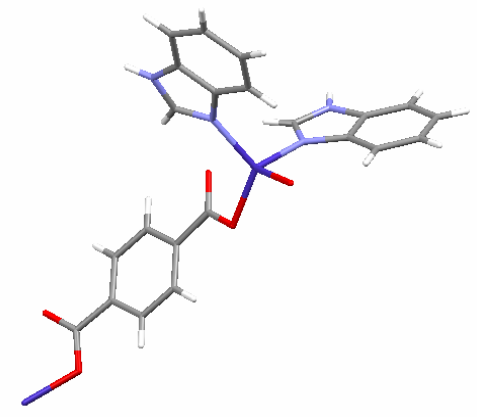

Figure 8. Catena-(( $\mu_{2}$-terephthalato, $\left.O, O^{\prime}\right)$-bis $(1 H$-benzimidazole $)$-cobalt(II)). ${ }^{26 a}$ 
The same authors obtained a polymeric nickel(II) compound from the isophthalic acid, Figure 9, where the nickel(II) ion is in a octahedral geometry, with two ionic isophtalate ligands, bridging the metal atoms through carboxyl groups forming polymeric chains, these chains are hydrogen bonded to each other and stabilized by $\pi-\pi$ stacking between the aromatic rings of the benzimidazole and those from the ligand. ${ }^{27}$

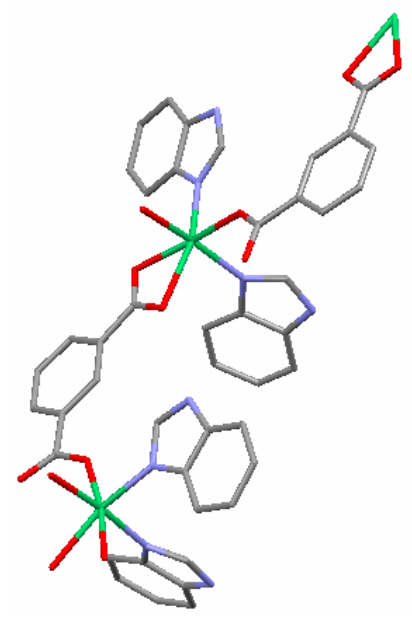

Figure 9. Catena-(bis(aqua-bis $\left(1 H\right.$-benzimidazole-N)- $\left(\mu_{2}\right.$-isophthalato- $\left.O, O^{\prime}, O^{\prime \prime}\right)$-nickel(II)) ${ }^{27}$

When aromatic hydroxybenzoic acids were reacted with copper(II), different coordination behavior of the metal ion was observed, depending on the $\mathrm{OH}$ substitution in the aromatic ring. The salicylate compound, consists of one-dimensional polymeric chains bridged by the salicylate anion, where the copper(II) atom presents a tetragonally distorted octahedral geometry, Figure 10a. ${ }^{28 a}$ While 3-hydroxybenzoic acid stabilizes two independent molecules in the unit cell: one of them is a mononuclear compound with the copper(II) atom in a square-planar coordination geometry formed by two benzimidazole molecules and two hydroxylbenzoate anions, stabilizing a trans isomer as observed in the previously described $\left[\mathrm{Cu}(\mathrm{bz})_{2} \mathrm{Br}_{2}\right]$, Figure $10 \mathrm{~b}$. ${ }^{28 \mathrm{~b}}$ The other molecule is a dimer of the previous one, formed by bridging hydroxybenzoate, where de copper(II) is in a square-pyramidal geometry. When changing from 3- to 4-hydroxylbenzoate anions, the metal atom is located in an inversion center, with a non-regular octahedral geometry, Figure $10 \mathrm{c}{ }^{28 c}$ On the other hand, a distorted square planar arrangement is stabilized by the copper(II) ion, in the complex containing 3,5-dihydroxybenzoate ligands, Figure 10d. ${ }^{28 \mathrm{~d}}$ All these compounds present $\pi-\pi$ stacking between aromatic rings, and an extensive $\mathrm{O}-\mathrm{H}^{\cdots} \mathrm{O}$ and $\mathrm{N}-$ $\mathrm{H}^{\cdots} \mathrm{O}$ hydrogen-bonding network. 


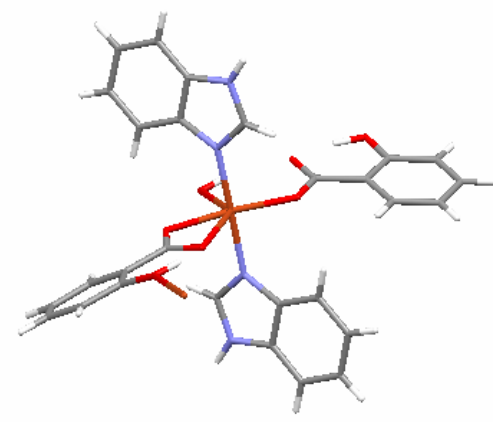

a

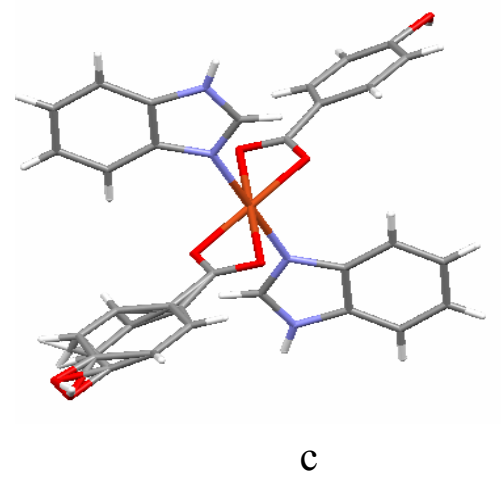

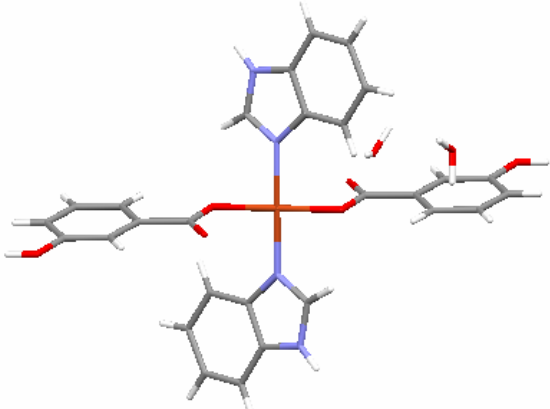

b

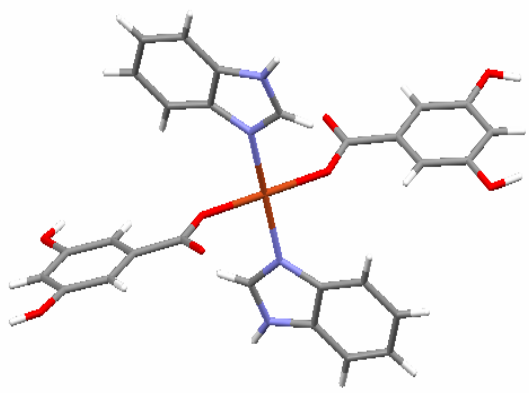

d

Figure 10. a) Catena-(( $\mu_{2}$-salicylato)-bis( $1 H$-benzimidazole $)-($ salicylato $)$-copper(II)); b) bis(1H-benzimidazole)-bis(3-hydroxybenzo)-copper(II);

c) bis-((1H-benzimidazole)-bis(4hydroxybenzoato- $\left.O, O^{\prime}\right)$-copper(II)); d) bis-((1H-benzimidazole)-bis(3,5-dihydroxybenzoato-O)copper(II)). ${ }^{28 a-28 d}$

Bukowska-Strzyzewska et. al. have studied the influence of increasing the length of the carbon chain in the carboxylic acids. Catena- $\left(\left(\mu_{2}\right.\right.$-trans-2-butene-1,4-dicarboxylato$\left.O, O^{\prime}, O^{\prime \prime}, O^{\prime \prime \prime}\right)$-aqua-bis(1H-benzimidazole)-copper(II)) and catena-(( $\mu_{2}$-adipato- $\left.O, O^{\prime}, O^{\prime \prime}, O^{\prime \prime}\right)$ aqua-bis( $1 H$-benzimidazole)-copper(II)), there is a water molecule bonded to the copper(II) ion, which is in a pentacoordinated geometry, Figure $11 \mathrm{a}^{29 \mathrm{a}, 29 \mathrm{~b}}$ While for the hexane-1,6 and octane1,8 dicarboxylate, two bidentate carboxylate oxygen atoms are in the equatorial positions, and in the axial positions two benzimidazole molecules complete the coordination sphere of the octahedral metal ion, in Figure $11 \mathrm{~b}$ the octane-1,8 dicarboxylate compound is shown. 


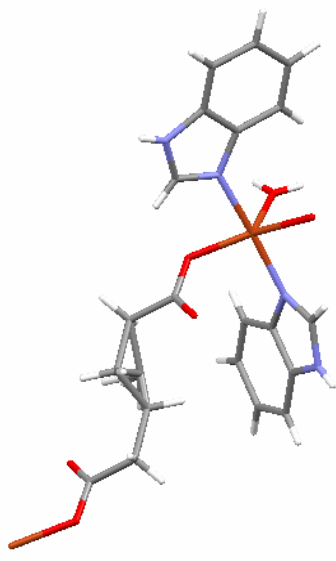

a

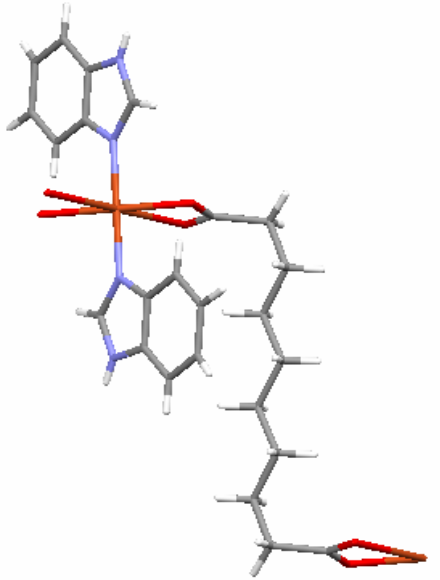

b

Figure 11. (a) Catena- $\left(\left(\mu_{2}\right.\right.$-trans-2-butene-1,4-dicarboxylato- $\left.O, O^{\prime}, O^{\prime \prime}, O^{\prime \prime \prime}\right)$-aqua-bis $(1 H$ benzimidazole)-copper(II)); (b) catena-[( $\mu_{2}$-octane-1,8-dicarboxylato- $\left.O, O^{\prime}, O^{\prime \prime}, O^{\prime \prime}\right)$-bis $(1 H$ benzimidazole)-copper(II)]. ${ }^{29 a, 29 c}$

Reedijk and co-workers, reported the compound catena-((tris $\left(\mu_{2}\right.$-pentane-1,5bis(carboxylato)-tetrakis(1H-benzimidazole)-di-copper(II)), Figure 12, where the carboxylate ions are monodentate and in a bridging mode, with pentacoordinated copper(II) ions. ${ }^{30}$

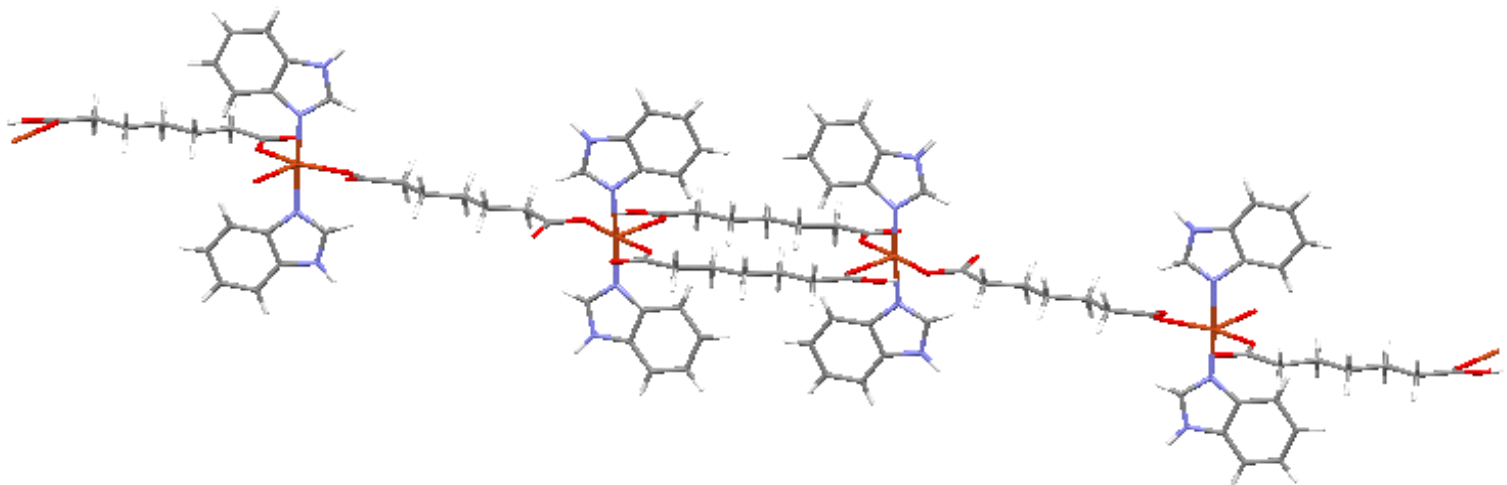

Figure 12. Catena-(tris $\left(\mu_{2}\right.$-pentane-1,5-bis(carboxylato))-tetrakis $(1 H$-benzimidazole)-dicopper(II)). ${ }^{30}$

Another example of a polymeric compound is catena-( $\mu_{3}-(3$-carboxylatophenoxyacetato$\left.O, O^{\prime}, O^{\prime \prime}, O^{\prime \prime \prime}\right)-\left(1 H\right.$-benzimidazole)-copper(II)), Figure $13 .{ }^{31}$ 


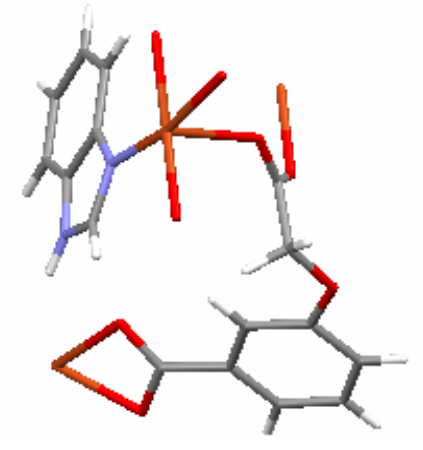

Figure 13. Catena-( $\mu_{3}-\left(3\right.$-carboxylatophenoxyacetato- $\left.O, O^{\prime}, O^{\prime \prime}, O^{\prime \prime}\right)-(1 \mathrm{H}-$ benzimidazole)copper(II)). ${ }^{31}$

In the case of the 5-fluorouracil acetate derivatives monomeric coordination compounds were obtained. In compound (bis(5-fluorouracil-1-acetate- $O$ )-diaqua-bis(1H-benzimidazole)cobalt(II)), the metal ion is in a octahedral geometry, as in the centrosymmetric nickel(II) compound (bis(5-fluoro-2,4-dioxo-1,2,3,4-tetrahydropyrimidine-1-acetato)-diaqua-bis(1Hbenzimidazole)nickel(II)), Figure 14. ${ }^{32 \mathrm{a}, 32 \mathrm{~b}}$

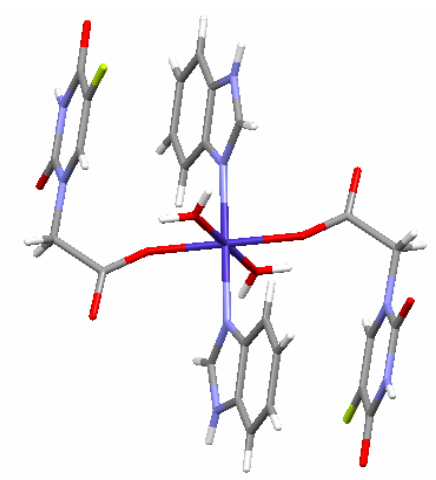

a

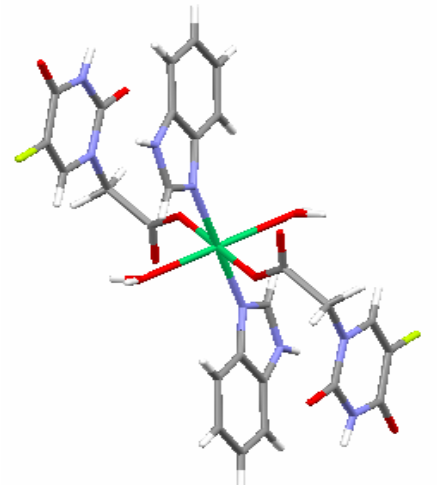

$\mathrm{b}$

Figure 14. (a) (bis(5-fluorouracil-1-acetate- $O)$-diaqua-bis(1H-benzimidazole)-cobalt(II)); (b) (bis(5-fluoro-2,4-dioxo-1,2,3,4-tetrahydropyrimidine-1-acetato)-diaqua-bis( $1 \mathrm{H}$-benzimidazole) nickel(II)). ${ }^{32 a, 32 b}$

Dimeric copper(II) compounds have been obtained with acetate bridges by BukowskaStrzyzewska ${ }^{33 a}$ and, with methacrylate by Zhou and co-workers. ${ }^{33 b}$ The coordination complexes have a dimeric copper arrangement through four carboxylate bridges, while the benzimidazole ligands are coordinated in the axial position, giving place to an octahedral arrangement for each copper(II) ion, Figure 15. 


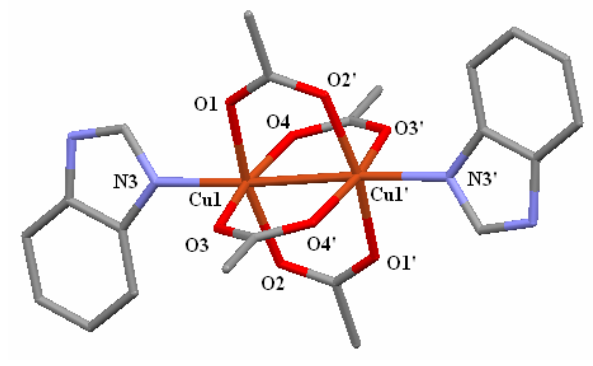

a

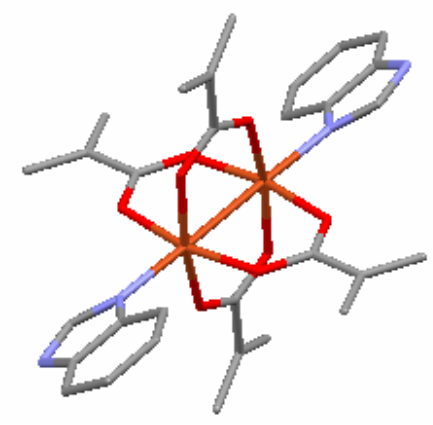

b

Figure 15. Dimeric copper(II) compounds with carboxylate bridges: (a) (tetrakis( $\mu_{2}$-acetato)bis( $1 H$-benzimidazole)-copper(II)); copper(II)). ${ }^{33 a, 33 b}$

(b) (tetrakis $\left(\mu_{2}\right.$-methacrylato)-bis( $1 H$-benzimidazole)-

Another type of a dimer was stabilized by the oxyacetate derivative in compound $\operatorname{bis}\left(\mu_{2}-\right.$ benzene-1,4-bis(oxyacetate)-diaqua-tetrakis( $1 H$-benzimidazole)-di-cobalt(II)), where the metal ion adopts an octahedral geometry, as shown in Figure $16 .{ }^{34}$

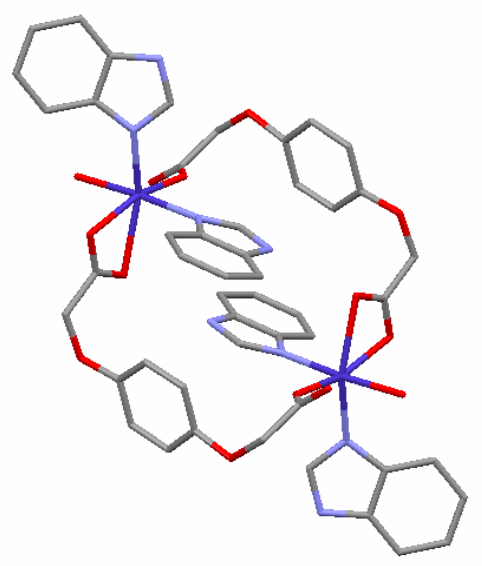

Figure 16. Dimeric structure of $\operatorname{bis}\left(\mu_{2}\right.$-benzene-1,4-bis(oxyacetate)-diaqua-tetrakis $(1 H$ benzimidazole)-di-cobalt(II)). ${ }^{34}$

There are some examples with tridentate ligands that will be discussed in this section. An example of a cobalt(II) coordination compound, with a ligand bearing three oxygen donor atoms, is the oxydiacetate complex, where the tridentate oxydiacetate dianion is bonded to the central metal ion in a facial configuration, and the octahedral $\mathrm{Co}^{\mathrm{II}}$ coordination sphere is completed by three benzimidazole ligands, as shown in Figure $17 \mathrm{a}^{35 \mathrm{a}} \mathrm{A}$ similar compound with a facial coordination mode is observed in the nickel(II) complex, with $L$-aspartate, where two oxygen and a nitrogen atoms are bonded to the central metal ion, Figure $17 \mathrm{~b} .{ }^{35 \mathrm{~b}}$ 


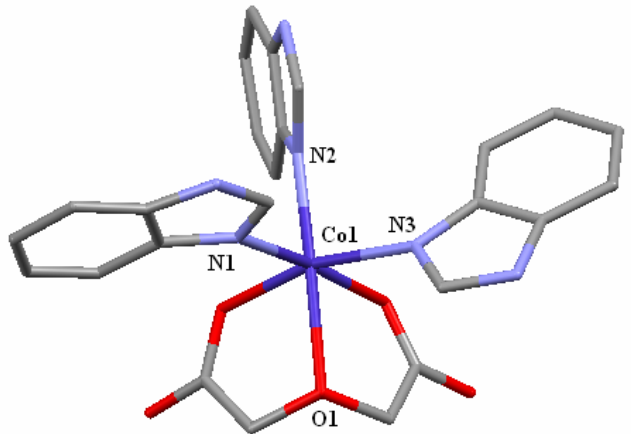

a

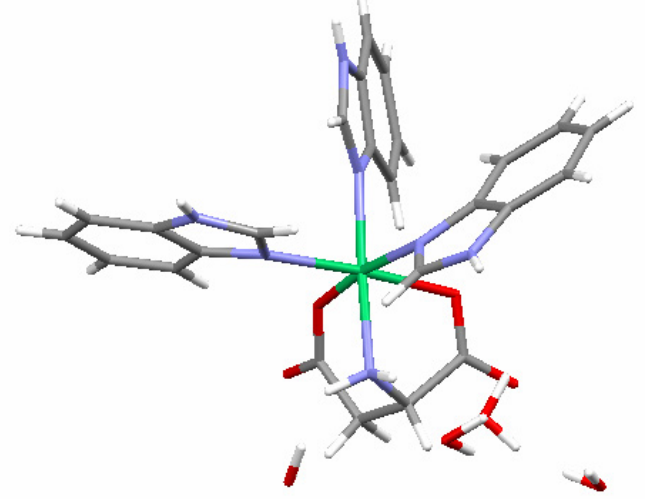

$\mathrm{b}$

Figure 17. (a) $\operatorname{Tris}\left(1 H\right.$-benzimidazole)-(oxydiacetate- $\left.\kappa^{3} O, O^{\prime}, O^{\prime \prime}\right)$-cobalt(II); (b) $\operatorname{tris}(1 H$ benzimidazole)-( $L$-aspartate). ${ }^{35 \mathrm{a}, 35 \mathrm{~b}}$

Iminodiacetato derivatives behave as tridentate ligands in benzimidazole complexes, as it has been shown by Niclos-Gutierrez, ${ }^{36 \mathrm{a}}$ and $\mathrm{Xu}^{36 \mathrm{~b}}$ Compounds (1H-benzimidazole)-(aqua)(iminodiacetato- $\left.N, O, O^{\prime}\right)$-copper(II), and tris( $1 H$-benzimidazole)-(iminodiacetato- $N, O, O^{\prime}$ )nickel(II) are depicted in Figure 18. In both compounds an iminodiacetate dianion is three coordinated in a facial mode through the nitrogen and the oxygen atoms. In the case of the nickel(II) compound, three benzimidazole ligands complete the coordination sphere, yielding a compound with the metal ion in a distorted octahedral geometry. The iminodiacetate chelate ring presents an envelope configuration and each benzimidazole displays a different orientation. This structure is analogous to that of its cobalt(II) derivative. ${ }^{36 c}$

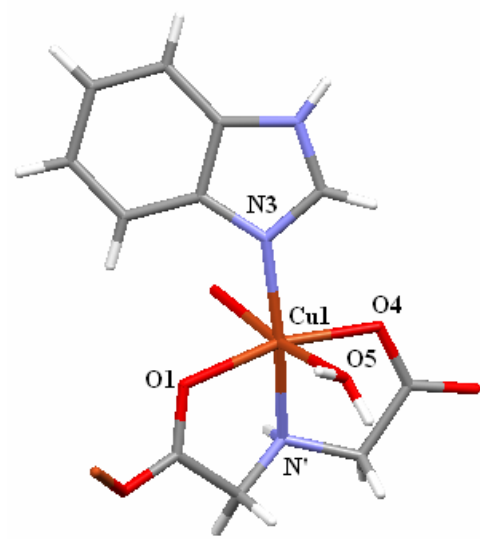

a

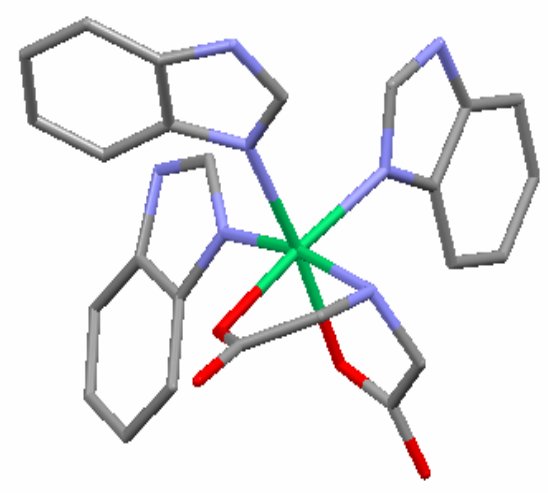

b

Figure 18. (a) (1H-benzimidazole)-(aqua)-(iminodiacetato- $\left.N, O, O^{\prime}\right)$-copper(II); (b) $\operatorname{tris}(1 H$ benzimidazole)-(iminodiacetato- $\left.N, O, O^{\prime}\right)$-nickel(II). ${ }^{36 a}, 36 \mathrm{~b}$ 


\section{2-Substituted benzimidazoles}

\subsection{Nitrogen monodentate compounds}

In this section a series of transition metal compounds with 2-monosubstituted derivatives will be discussed. They all coordinate to the metal ion through N3 of the benzimidazolic nitrogen.

\subsubsection{2-uroyl, 2-carbamate and 2-benzothiazole coordination compounds}

R. Contreras et. al. have studied the coordination behavior of 2-benzimidazole derivatives where either $\mathrm{O}$ or $\mathrm{S}$ atoms were introduced in the substituted groups. Some examples of these groups are uroyl, carbamate and thiazole, as discussed below.

2-Uroylbenzimidazole ( $\mathrm{ubz}$ ) and 2-benzimidazolecarbamate, are planar systems bearing $\mathrm{sp}^{2}$ nitrogen and oxygen atoms, with lone pairs for coordination. They may be represented by different conformers and tautomers, where the presence of intramolecular interactions, such as hydrogen bonds, stabilized some isomers and dimeric systems, as observed in solution and in solid state. In Figure 19 some of the tautomers and conformers of 2-uroyl-benzimidazole are represented, ${ }^{37 \mathrm{a}}$ and the structure of 2-benzimidazolecarbamate. ${ }^{37 \mathrm{~b}}$
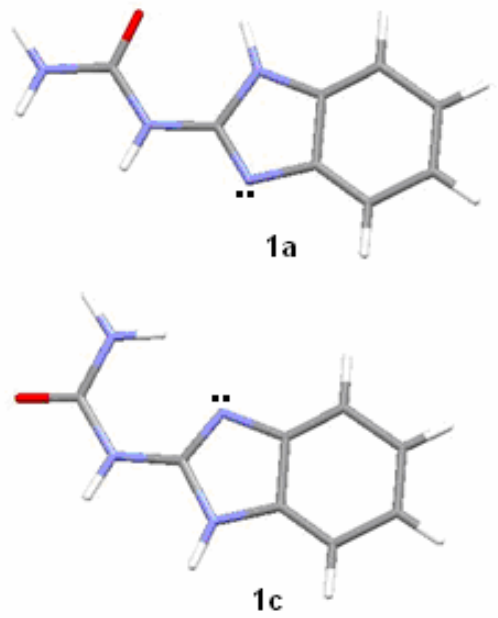

$1 \mathrm{c}$

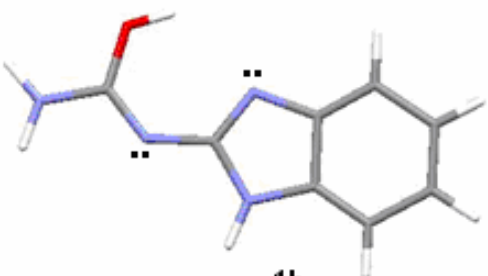

1b

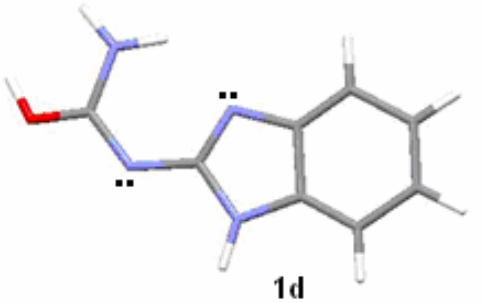

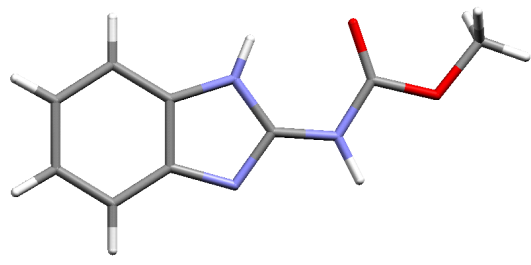

2

Figure 19. Tautomers and conformers of 2-uroyl-benzimidazole (1a, 1b, 1c, 1d). ${ }^{37 a}$ Structure of 2-benzimidazolecarbamate (2). ${ }^{37 b}$ 
Despite of the presence of oxygen atoms as possible coordinating sites towards transition metal ions, both ubz and mbc derivatives behaved as monodentate ligands, bonded through the benzimidazolic nitrogen to the metal atom, as illustrated by the carbamate (mbc) compound, $\left[\mathrm{Co}(\mathrm{mbc})_{2} \mathrm{Cl}_{2}\right] \cdot \mathrm{CH}_{3} \mathrm{OH}$, Figure 20. In this complex, the central metal ion acquires a tetrahedral geometry. ${ }^{37}$ Similar structures are observed in $\left[\mathrm{Zn}(\mathrm{ubz})_{2} \mathrm{Cl}_{2}\right], \quad\left[\mathrm{Zn}(\mathrm{ubz})_{2} \mathrm{Br}_{2}\right]$ and $\left[\mathrm{Cd}(\mathrm{ubz})_{2}\left(\mathrm{NO}_{3}\right)_{2}\right]$ with 2-uroylbenzimidazole (ubz).

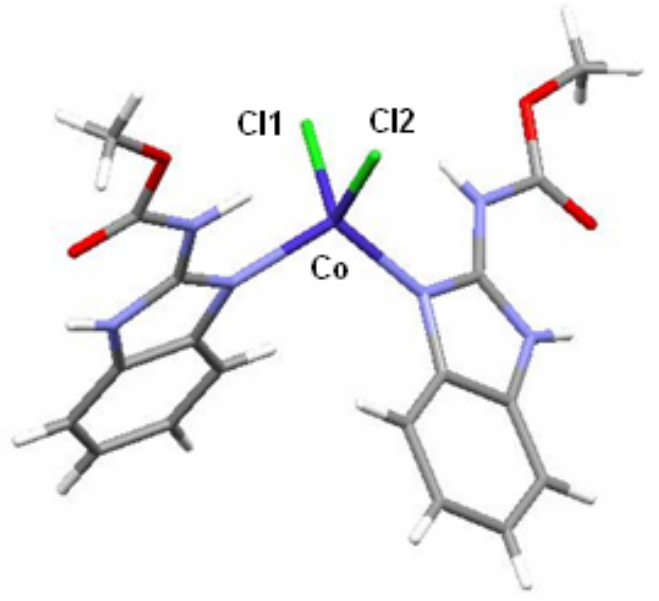

Figure 20. Cobalt(II) 2-methyl-carbamate compound $\left[\mathrm{Co}(\mathrm{mbc})_{2} \mathrm{Cl}_{2}\right] \cdot \mathrm{CH}_{3} \mathrm{OH} \cdot{ }^{37}$

The synthesis and characterization of coordination compounds of 2-aminobenzothiazole (btz), was studied by the same group. They showed that bonding occurs through N3, similar to their analogous mbc compounds. The tetracoordinated compounds $\left[\mathrm{Co}\left(\mathrm{btz}-\mathrm{SMe}_{2}\right)_{2} \mathrm{Cl}_{2}\right]$ and $\left[\mathrm{Zn}(\text { btz-SMe })_{2} \mathrm{Cl}_{2}\right]$, stabilized different molecular aggregates through intermolecular hydrogen bonding. The conformation of the ligand gave the $S, S$ isomer, as shown in Figure $21 .^{38,39}$

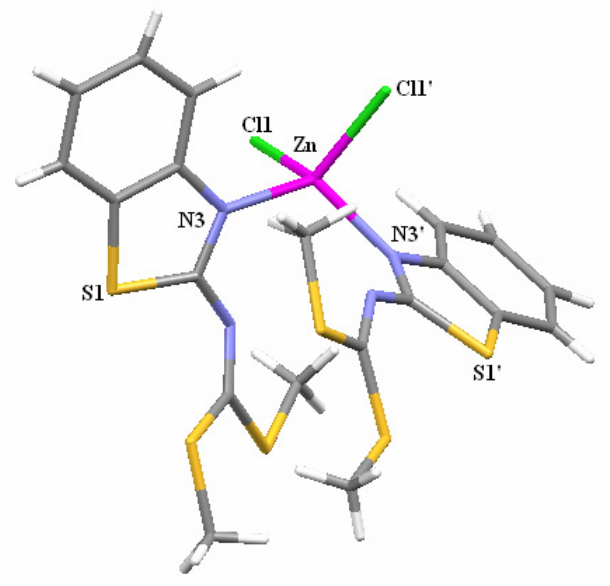

Figure 21. Zinc(II) 2-aminobenzothiazole (btz) derivative, $\left[\mathrm{Zn}\left(\mathrm{btz}-\mathrm{SMe}_{2}\right)_{2} \mathrm{Cl}_{2}\right] .{ }^{39}$ 


\section{2. $(\mathrm{N}, \mathrm{N}) ;(\mathrm{N}, \mathrm{O}) ;(\mathrm{N}, \mathrm{S})$; chelate compounds}

\subsection{1. ( $N, N)$ coordination compounds}

3.2.1.1. 2-(2-Benzothiazolylaminzole and 2-(2-aminobenzothiazolyl-amino)benzoxazoleo) benzothia. Contreras and co-workers had previously reported heterocyclic systems derived from benzothiazole. Bis-benzothiazolyl amine forms a six membered ring, by inclusion of a metal(II) ion in a planar delocalized system, alternating $\mathrm{sp}^{2}$ carbon and nitrogen atoms. In all the complexes this ligand is deprotonated and coordinated through $\mathrm{N} 3$ and N13, in a bidentate mode. Compounds containing this ligand present different geometries: tetrahedral for cobalt(II), zinc(II) and mercury(II), octahedral and square pyramidal for nickel(II). A related ligand, btz-boz, (2-(2aminobenzothiazolylamino)benzoxazole), was also synthesized by the same group and its coordination chemistry toward metal ions investigated. The nickel(II) compound [Ni(btzboz) $\left.(\mathrm{OAc})(\mathrm{MeOH})_{2}\right]$ contains one btz-boz bonded to the metal ion, forming a pentacyclic frame, a bidentate acetate, and two trans-methanol molecules completing the hexacoordination, Figure $22 .{ }^{40}$

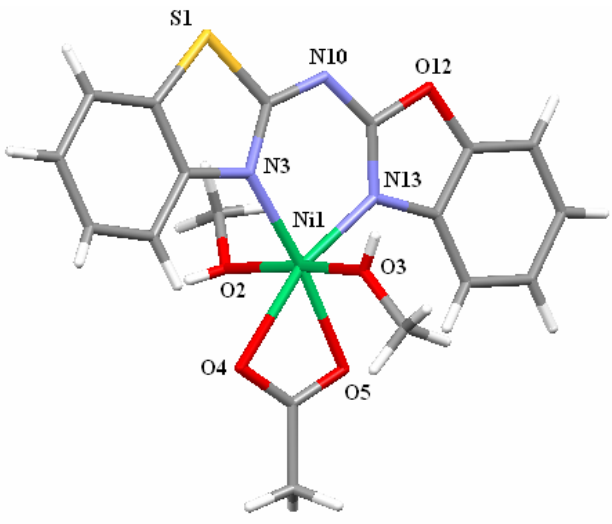

Figure 22. $\left[\mathrm{Ni}(\mathrm{btz}-\mathrm{boz})(\mathrm{OAc})(\mathrm{MeOH})_{2}\right]^{40}$

3.2.1.2 - 2-(4'-Thiazolyl)benzimidazole. Coordination compounds containing thiabendazole, 2(4'-thiazolyl)benzimidazole (4tbz), form bis-chelate and tris-chelate compounds, as reported by Barba-Behrens et. al. In all cases, the ligand coordinates to the metal (cobalt(II), nickel(II), copper(II), zinc(II), cadmium(II) and mercury(II)) through the imidazolic and thiazolic nitrogen atoms; the heterocyclic sulfur does not interact with the metal. The bis-chelate compounds stabilized the cis-isomers, while the tris-chelate complexes gave two types of isomers: the cobalt compound is of $\mathrm{C} 1$ symmetry, and the nickel and cadmium complexes are of C3 symmetry, see Figure 23b. For cobalt(II), nickel(II) and copper(II) compounds, a similar interaction with both nitrogen atoms was found, as the M-N bond lengths are within the range, (1.97-2.09 $\AA$ ) Figure $23 .^{41}$ 


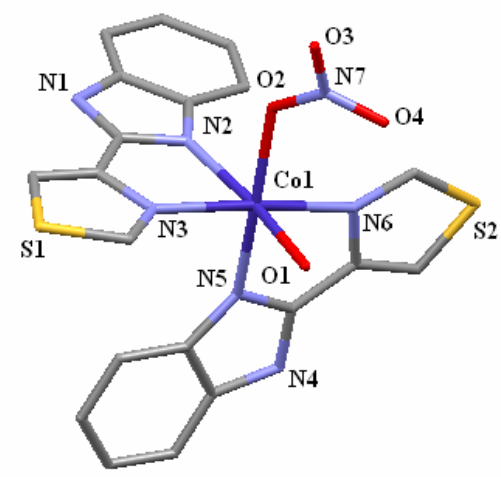

$\mathrm{a}$

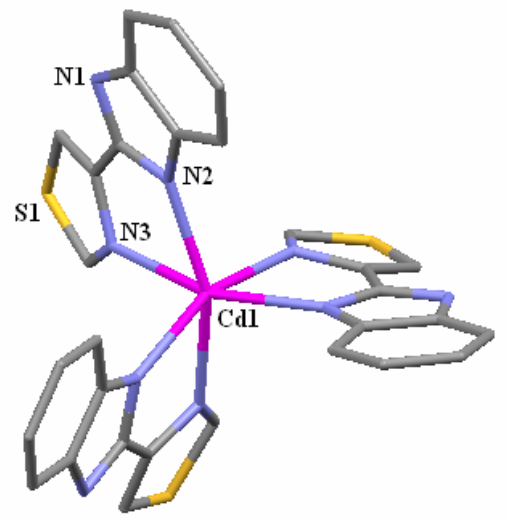

b

Figure 23. Cations $(\mathrm{a})\left[\mathrm{Co}(4 \mathrm{tbz})_{2}\left(\mathrm{H}_{2} \mathrm{O}\right) \mathrm{NO}_{3}\right]^{2+}$ and b) $\left[\mathrm{Cd}(4 \mathrm{tbz})_{3}\right]^{2+} \cdot 41$

Copper(II) compounds with thiabendazole have been investigated with different counterions, such as chloride, nitrate and butanedioate.

In $\left[\mathrm{Cu}(\mathrm{tbz})_{2} \mathrm{Cl}\right] \mathrm{Cl} \cdot \mathrm{H}_{2} \mathrm{O} \cdot \mathrm{EtOH}$ copper(II) is pentacoordinated, with a distorted trigonal bipyramidal geometry, see Figure $24 .^{42}$ In this context, Muthiah and co-workers reported $\left[\mathrm{Cu}(\mathrm{tbz})\left(\mathrm{NO}_{3}\right)_{2}\left(\mathrm{H}_{2} \mathrm{O}\right)_{2}\right]$, where the copper atom has a distorted octahedral geometry, with one bidentate neutral ligand, two coordinated nitrates (trans), and two $\mathrm{H}_{2} \mathrm{O}$ molecules. ${ }^{43}$

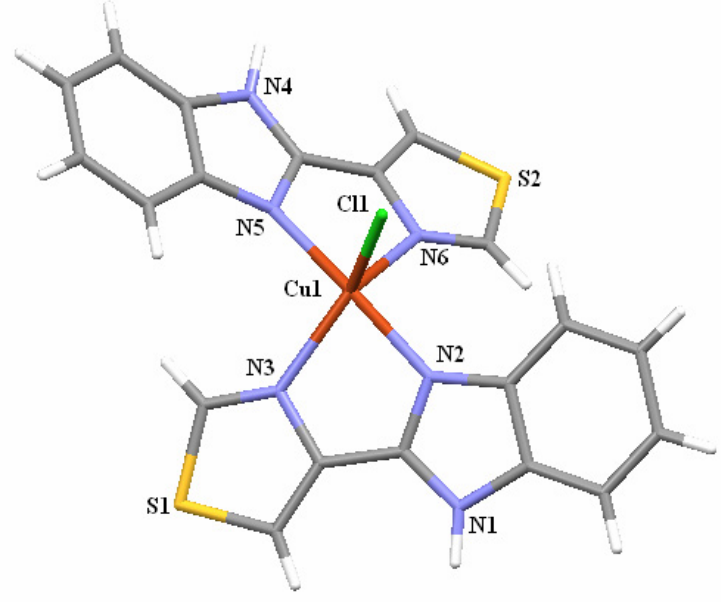

Figure 24. $\left[\mathrm{Cu}(\mathrm{tbz})_{2} \mathrm{Cl}\right] \mathrm{Cl} \cdot \mathrm{H}_{2} \mathrm{O} \cdot \mathrm{EtOH}^{4}{ }^{42}$

3.2.1.3 2-((5-Methylpyrazol-3-yl)methyl))benzimidazole. M. Pierrot and co-workers reported several complexes that contain 2-((5-methylpyrazol-3-yl)methyl)benzimidazole, where the ligand behaves in a bidentate mode. The compounds dichloro-(2-((5-methyl-1H-pyrazol-3yl)methyl)-1H-1,3-benzimidazole)-copper(II), $\quad\left[\mathrm{Cu}(\mathrm{mpbz}) \mathrm{Cl}_{2}\right], \quad$ and $\operatorname{bis}\left(\mu_{2}\right.$-chloro)-bis(2-((5methyl-1H-pyrazol-3-yl)methyl)-1H-1,3-benzimidazole)-dichloro-di-cadmium(II), $\left.\mathrm{Cd}(\mathrm{mpbz}) \mathrm{Cl}_{2}\right]$ 
are shown in Figure 25. The copper(II) complex is a monomer, with a ligand and two chlorine atoms bonded to the metal ion, in a tetrahedral geometry. While for cadmium(II), a dimeric compound is obtained, where the metal atoms are bridged by two chlorides, each of them bonded to a ligand and a chlorine atom, in a square-pyramidal geometry. ${ }^{44}$

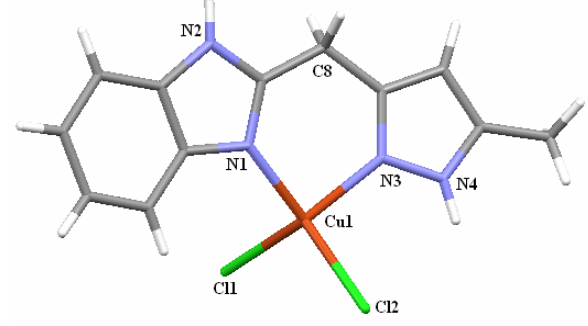

a

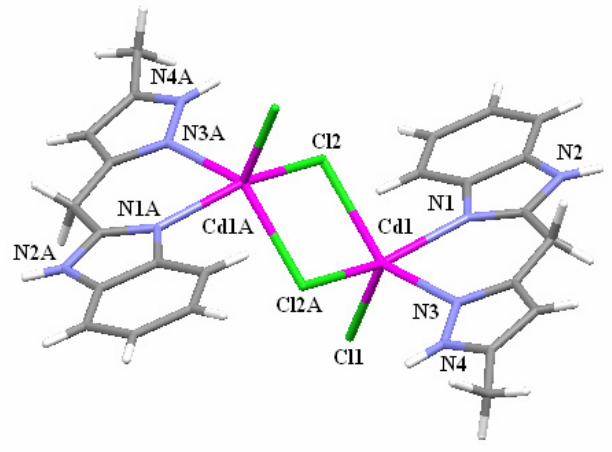

$\mathrm{b}$

Figure 25. (a) $\left[\mathrm{Cu}(\mathrm{mpbz}) \mathrm{Cl}_{2}\right]$ and (b) $\left[\mathrm{Cd}(\mathrm{mpbz}) \mathrm{Cl}_{2}\right] .{ }^{44}$

Two related compounds: $\left[\mathrm{Ni}(\mathrm{mpbz})_{2}\left(\mathrm{H}_{2} \mathrm{O}\right)\right] \mathrm{Cl}_{2} \cdot 2 \mathrm{H}_{2} \mathrm{O}$ and $\left[\mathrm{Co}(\mathrm{mpbz})_{2} \mathrm{H}_{2} \mathrm{O}\right] \mathrm{Cl}_{2} \cdot\left(\mathrm{C}_{3} \mathrm{H}_{6} \mathrm{O}\right)$ were reported by the same authors,. In these complexes, two mpbz molecules and two water molecules are coordinated to the central metal ion, a distorted cis-octahedral geometry is adopted by both metal ions, as shown in Figure 26. ${ }^{45,46}$

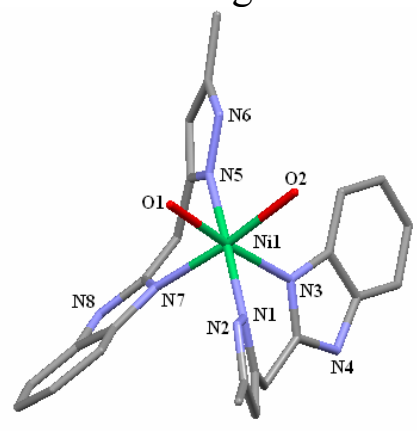

a

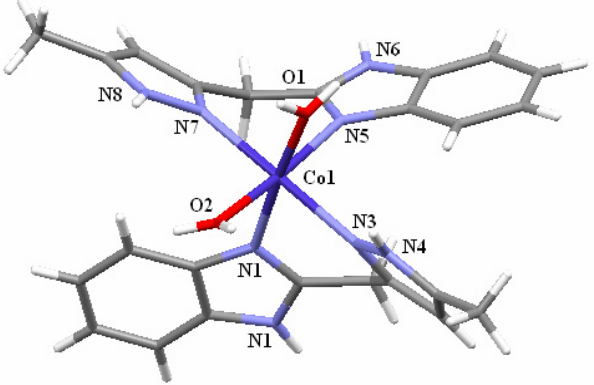

$\mathrm{b}$

Figure 26. (a) $\left[\mathrm{Ni}(\mathrm{mpbz})_{2}\left(\mathrm{H}_{2} \mathrm{O}\right)\right] \mathrm{Cl}_{2} \cdot 2 \mathrm{H}_{2} \mathrm{O}$ and (b) $\left[\mathrm{Co}(\mathrm{mpbz})_{2} \mathrm{H}_{2} \mathrm{O}\right] \mathrm{Cl}_{2} \cdot\left(\mathrm{C}_{3} \mathrm{H}_{6} \mathrm{O}\right) .{ }^{45,46}$

3.2.1.4 2-Guanidinobenzimidazole. 2-Guanidinobenzimidazole ( $2 \mathrm{gb}$ ) is a polyfunctional planar molecule with a delocalized $\pi$ electronic system, five nitrogen atoms that may act as basic centers and five labile $\mathrm{N}-\mathrm{H}$ bonds. Theoretical calculations were carried out to determine which $2 \mathrm{gb}$ isomers may be involved in coordination (see Figure 27), as well as, the structures of the coordination compounds. According to the calculations, tautomer A of $2 \mathrm{gb}$ is the most stable species in the solid state, according with its X-ray crystal structure. However, it is important to mention that isomer B-IV yields chelates upon coordination to metal ions. ${ }^{47}$ 


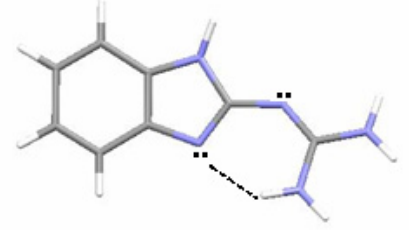

A

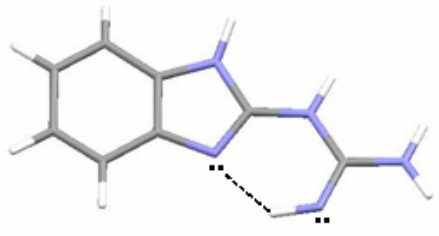

B- III

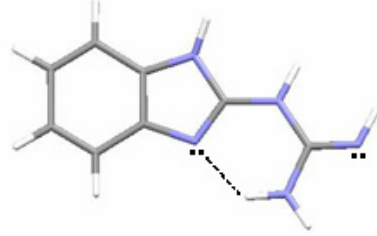

B-I

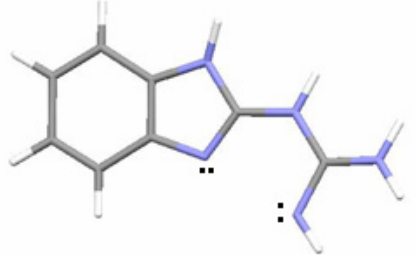

B-IV

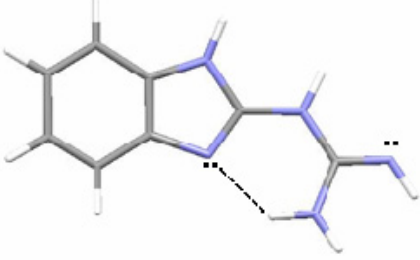

B-II

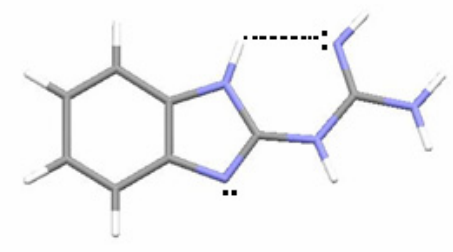

B- $V$

Figure 27. Tautomers A and B of 2-guanidinobenzimidazole, and isomers of tautomer B. ${ }^{47}$

The reactions of 2-guanidinobenzimidazole with metal ions of the type $\mathrm{M}^{\mathrm{II}}(\mathrm{Co}, \mathrm{Ni}, \mathrm{Cu}$ and $\mathrm{Zn}$ ) under different conditions have been discussed by Barba-Behrens and co-workers. Different types of compounds have been obtained, where the ligand coordinates as monodentate or bidentate, and different number of $2 \mathrm{gb}$ molecules coordinate to the ligand.

Compounds of the type $\left[\mathrm{M}(2 \mathrm{gb})_{2}\right] \mathrm{X}_{2} \cdot \mathrm{xH}_{2} \mathrm{O}$, where $\mathrm{X}^{-}=\mathrm{Cl}, \mathrm{Br}, \mathrm{NO}_{3}$ and $\mathrm{AcO}$ and $\mathrm{M}^{\mathrm{II}}=\mathrm{Ni}$; for $\mathrm{M}^{\mathrm{II}}=\mathrm{Cu}, \mathrm{X}^{-}=\mathrm{Br}, \mathrm{NO}_{3}$ and $\mathrm{AcO}$, where the ligand coordinates in a bidentate manner through N3 and N12, were obtained and characterized. Also, compounds of the type $\left[\mathrm{M}(2 \mathrm{gb}) \mathrm{X}_{2}\right] \cdot \mathrm{XH}_{2} \mathrm{O}, \mathrm{X}^{-}=\mathrm{Cl}, \mathrm{Br}, \mathrm{M}^{\mathrm{II}}=\mathrm{Cu}, \mathrm{Zn}$. For $\mathrm{M}^{\mathrm{II}}=\mathrm{Co}$, the following compounds were obtained $\left[\mathrm{Co}(2 \mathrm{gb}) \mathrm{Cl}_{2}\left(\mathrm{H}_{2} \mathrm{O}\right)_{2}\right] \cdot 5 \mathrm{H}_{2} \mathrm{O},\left[\mathrm{Co}(2 \mathrm{gb})_{2} \mathrm{Cl}_{2}\right] \cdot 3 \mathrm{H}_{2} \mathrm{O},\left[\mathrm{Co}(2 \mathrm{gb})_{2}\left(\mathrm{H}_{2} \mathrm{O}\right)_{2}\right]\left(\mathrm{NO}_{3}\right)_{2} \cdot 4 \mathrm{H}_{2} \mathrm{O}$, and $\left[\mathrm{Co}(2 \mathrm{gb})_{2}\left(\mathrm{H}_{2} \mathrm{O}\right)_{2}\right](\mathrm{OAc})_{2}{ }^{48}$

In summary, two different types of coordination compounds were found. In the first type, the ligand is bonded to the metal ion in a chelating mode through the imidazolic nitrogen atom, N3 and the guanidino nitrogen atom, N12; which is the case for most of the complexes. The second type of coordination behavior was observed in the cobalt(II) compounds, where the ligand coordinates as monodentate through the imidazolic N3; the structure is tetrahedral, Figure $28 .^{49}$ With two chelating $2 \mathrm{gb}$ molecules a square-planar geometry was stabilized. On the other hand, for those compounds in which only one ligand is in the coordination sphere, the structure was either tetrahedral (copper and zinc; chloride and bromide) or octahedral (cobalt). ${ }^{48}$ 


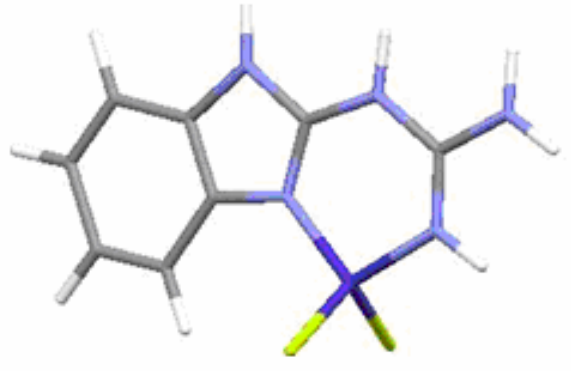

Td

Figure 28. Suggested structure for $\left[\mathrm{Co}(2 \mathrm{gb}) \mathrm{Cl}_{2}\right] .{ }^{49}$

Reedijk et al. have also investigated the reactions of $2 \mathrm{gb}$ with copper(II), using its triflate and perchlorate salts. The synthesis and characterization of two copper(II) isomers, purple $\alpha$ $\mathrm{Cu}(2 \mathrm{gb})_{2}\left(\mathrm{CF}_{3} \mathrm{SO}_{3}\right)_{2}$ and green $\beta-\mathrm{Cu}(2 \mathrm{gb})_{2}\left(\mathrm{CF}_{3} \mathrm{SO}_{3}\right)_{2}$, with different positions of the triflate anions has been reported. In the green compound one of the triflate anions is at a long, semicoordination distance, while in the purple compound the anions are at a much longer distance. ${ }^{50}$ The crystal structures of these isomers, Figure 29, is also compared with that of the green colored $\left[\mathrm{Cu}(2 \mathrm{gb})_{2}\right]\left(\mathrm{ClO}_{4}\right)_{2} \cdot \mathrm{H}_{2} \mathrm{O},{ }^{50 \mathrm{~b}}$ and is concluded that they exhibit a similar distorted tetrahedron arrangement around $\mathrm{Cu}(\mathrm{II})$, although both green compounds have a dihedral angle of nearly $40^{\circ}$, while that of the purple compound is of $37^{\circ}$. These distortions only occur at the copper(II) compounds and may be related to the electronic properties of the $\mathrm{Cu}^{\mathrm{II}}$ ion. ${ }^{50 \mathrm{a}}$

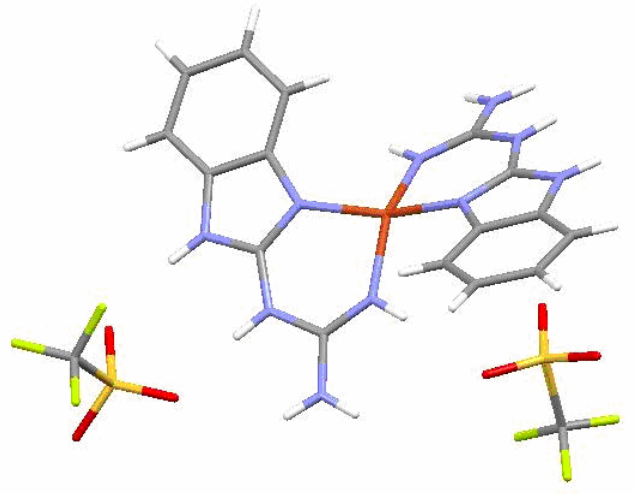

a

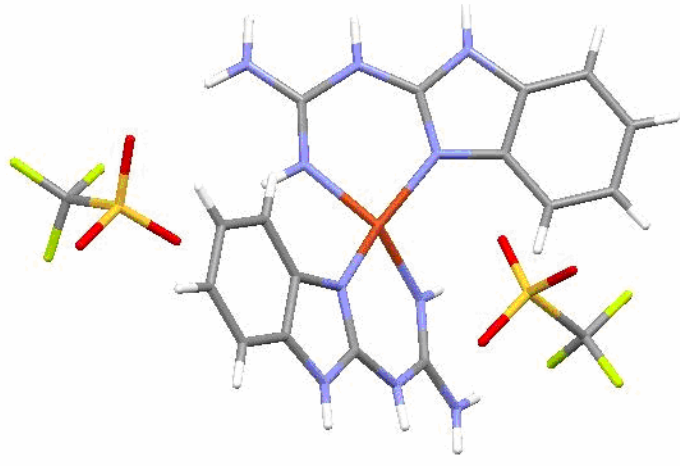

b

Figure 29. (a) $\alpha-\mathrm{Cu}(2 \mathrm{gb})_{2}\left(\mathrm{CF}_{3} \mathrm{SO}_{3}\right)_{2}$ and (b) $\beta-\mathrm{Cu}(2 \mathrm{gb})_{2}\left(\mathrm{CF}_{3} \mathrm{SO}_{3}\right)_{2}$. ${ }^{50 \mathrm{a}}$

In 1997, Contreras et. al. investigated the protonation, coordination and methylation sites of $2 \mathrm{gb}$. The protonation of $2 \mathrm{gb}$ was studied by NMR, where the shift to low energy of the ${ }^{13} \mathrm{C}$ NMR signals shown in Figure 30 was observed. ${ }^{51}$ 


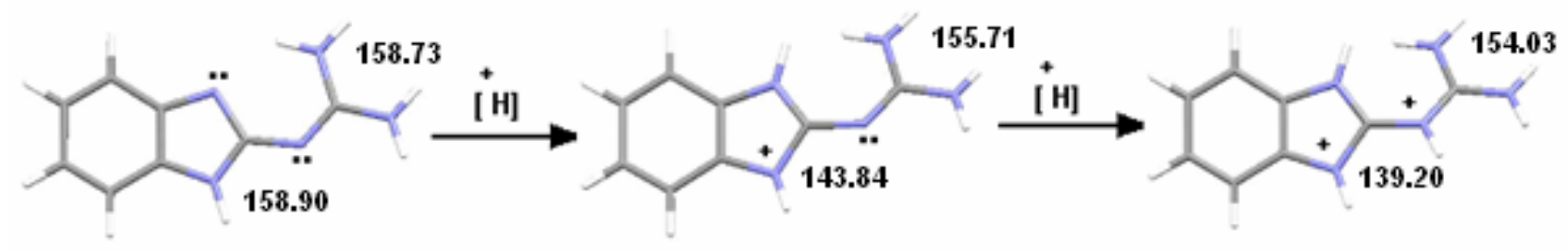

Figure 30. Protonation of 2-guanidinobenzimidazole. ${ }^{51}$

The X-ray diffraction structure of a $\mathrm{Ni}^{\mathrm{II}}$ compound, where $2 \mathrm{gb}$ is deprotonated and therefore monoanionic, was obtained. Nickel(II) is coordinated to two deprotonated $2 \mathrm{gb}$ ligands in a square-planar geometry through the imidazolic N3 and the guanidino N12, see Figure $31 .^{51}$

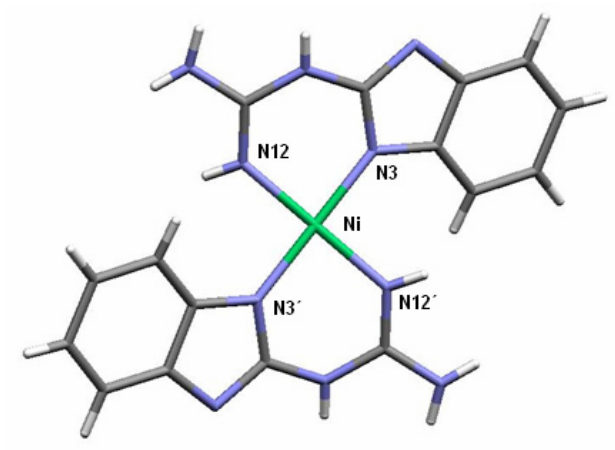

Figure 31. X-ray structure of $\left[\mathrm{Ni}(2 \mathrm{gb})_{2}\right] \cdot \mathrm{CH}_{3} \mathrm{OH} \cdot{ }^{51}$

The reaction of $2 \mathrm{gb}$ with zinc nitrate in hot methanol afforded a crystalline compound in which two 2-guanidinobenzimidazole ligands were coordinated through N3 and N12 atoms to the zinc(II), Figure 32. In this compound $2 \mathrm{gb}$ is bonded through the imidazole ring and guanidine group, it id important to mention that both ligands had protons at N1 and N10. The zinc(II) complex was studied by ${ }^{1} \mathrm{H}$ and ${ }^{13} \mathrm{C}$ NMR spectroscopy, which confirmed that the presence of a proton at the $\mathrm{N}$ atom directly bonded to the benzimidazole induces a shift of the $\mathrm{C}-2$ signal to lower frequencies. 


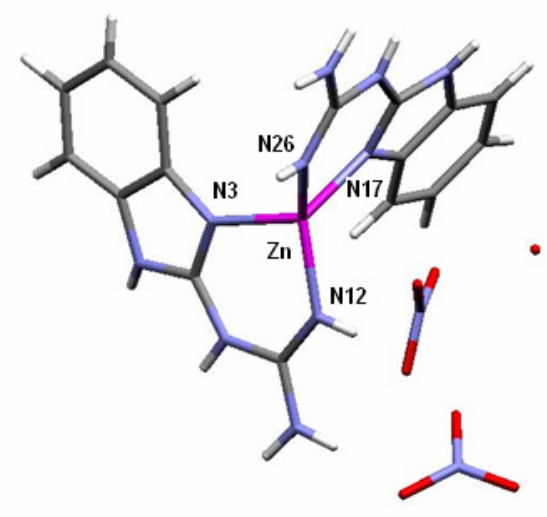

Figure 32. $\left[\mathrm{Zn}(2 \mathrm{gb})_{2}\right]\left(\mathrm{NO}_{3}\right)_{2} \cdot \mathrm{H}_{2} \mathrm{O} .{ }^{51}$

Similar structures were obtained by Castillo-Blum and co-workers, when either cobalt(III) or chromium(III) compounds, ${ }^{52}$ in both cases, the metal ions are two inert centers toward substitution processes. Coordination compounds of cobalt(III) have been used to study electrontransfer reactions with metalloproteins, such as plastocyanin and ferredoxin. ${ }^{53}$ On the other hand, the redox inactive chromium(III) complexes inhibit protein oxidation by positively charged coordination compounds. NMR studies employing reduced plastocyanin and chromium(III) coordination compounds have helped in determining the binding site of the protein.

The cobalt(III) coordination compounds with 2-guanidinobenzimidazole (2gb): $\left[\mathrm{Co}(2 \mathrm{gb})_{3}\right] \mathrm{Cl}_{2}\left(\mathrm{NO}_{3}\right) \cdot \mathrm{H}_{2} \mathrm{O}, \quad\left[\mathrm{Co}(2 \mathrm{gb})_{3}\right] \mathrm{Cl}\left(\mathrm{NO}_{3}\right)_{2} \cdot \mathrm{H}_{2} \mathrm{O}, \quad\left[\mathrm{Co}(2 \mathrm{gb})_{3}\right] \mathrm{Cl}_{3} \cdot 3 \mathrm{H}_{2} \mathrm{O} \quad$ and $\left[\mathrm{Co}(2 \mathrm{gb})_{3}\right]\left(\mathrm{Cl}_{3} \mathrm{CCOO}\right)_{3} \cdot \mathrm{H}_{2} \mathrm{O}$, were synthesized and characterized. ${ }^{1} \mathrm{H},{ }^{13} \mathrm{C}$ and $2 \mathrm{D}$ NMR spectra together with the X-ray diffraction data for the distorted octahedral $\left[\mathrm{Co}(2 \mathrm{gb})_{3}\right]^{3+}$ cation showed that only the mer isomer was obtained, Figure 33. The crystal space group is $P_{1}$ therefore, the crystal must contain a racemic mixture of the $\Lambda$ and $\Delta$ isomers. ${ }^{54}$

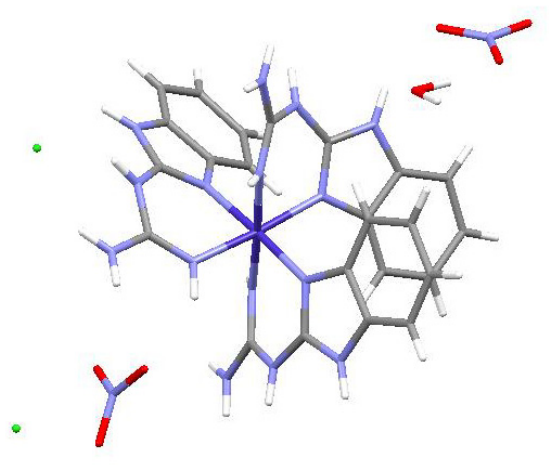

Figure 33. $\left[\mathrm{Co}(2 \mathrm{gb})_{3}\right] \mathrm{Cl}_{2}\left(\mathrm{NO}_{3}\right) \cdot \mathrm{H}_{2} \mathrm{O} .{ }^{54}$

The syntheses and characterization of chromium(III) complexes with 2guanidinobenzimidazole $(2 \mathrm{gb}),\left[\mathrm{Cr}(2 \mathrm{gb})_{3}\right] \mathrm{Cl}\left[\mathrm{ZnCl}_{4}\right] \cdot \mathrm{CH}_{3} \mathrm{OH},\left[\mathrm{Cr}(2 \mathrm{gb})_{3}\right] \mathrm{Cl}_{3} \cdot 4 \mathrm{H}_{2} \mathrm{O},\left[\mathrm{Cr}_{2}(2 \mathrm{gb})_{4}(\mu-\right.$ 
$\left.\mathrm{OH})_{2}\right]\left(\mathrm{ClO}_{4}\right)_{4} \cdot 5 \mathrm{H}_{2} \mathrm{O}$ were reported. The reaction of $2 \mathrm{gb}$ with $\mathrm{Cr}(\mathrm{II})$ in aqueous solution yielded a dinuclear compound. $\left[\mathrm{Cr}_{2}(2 \mathrm{gb})_{4}(\mu-\mathrm{OH})_{2}\right]\left(\mathrm{ClO}_{4}\right)_{4} \cdot 5 \mathrm{H}_{2} \mathrm{O}$ was the first X-ray characterized $\mathrm{Cr}(\mathrm{III})$ complex containing $2 \mathrm{gb}$ as ligand. The dinuclear cation $\left[\mathrm{Cr}_{2}(2 \mathrm{gb})_{4}(\mu-\mathrm{OH})_{2}\right]^{4+}$ is depicted in Figure 34. The $(\mu-\mathrm{OH})_{2}$ bridge is symmetric and the metal-metal separation, is similar to that reported for other complexes containing the $\mathrm{Cr}_{2}(\mu-\mathrm{OH})_{2}$ fragment. Each $\mathrm{Cr}(\mathrm{III})$ ion coordinates two $2 \mathrm{gb}$ ligands. ${ }^{55}$

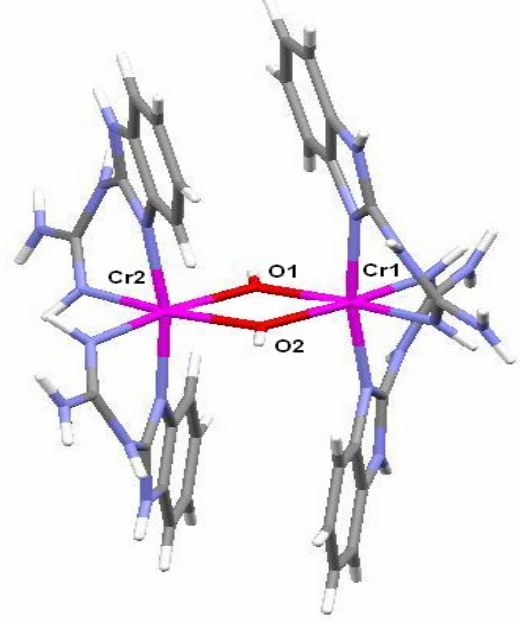

Figure 34. $\left[\mathrm{Cr}_{2}(2 \mathrm{gb})_{4}(\mu-\mathrm{OH})_{2}\right]\left(\mathrm{ClO}_{4}\right)_{4} \cdot 5 \mathrm{H}_{2} \mathrm{O} \cdot{ }^{55}$

The effect on photosynthesis of three isostructural compounds was investigated: $\left[\mathrm{Cr}(2 \mathrm{gb})_{3}\right] \mathrm{Cl}\left(\mathrm{ZnCl}_{4}\right),\left[\mathrm{Cr}(2 \mathrm{gb})_{3}\right] \mathrm{Cl}_{3}$, and $\left[\mathrm{Co}(2 \mathrm{gb})_{3}\right] \mathrm{Cl}_{3}$, where all of them behave as Hill reaction inhibitors. $^{52}$

3.2.1.5 2-Aminomethylbenzimidazole. Hui-Zhong Kou and co-workers reported complexes of the ligand 2-aminomethylbenzimidazole (2Hamb), with copper(II) and nickel(II). The structure of copper(II) complexes: $\left[\mathrm{Cu}(2 \mathrm{Hamb})_{2}\left(\mathrm{ClO}_{4}\right)_{2}\right]$ and $\left.\left[\mathrm{Cu}(2 \mathrm{Hamb})_{2}(\mathrm{dca})_{2}\right)\right]$, where dca $=$ $\mathrm{N}(\mathrm{CN})_{2}$ is discussed. In both cases $2 \mathrm{Hamb}$ behaves as a bidentate ligand; the geometry around each metal ion is octahedral. For $\left[\mathrm{Cu}(2 \mathrm{Hamb})_{2}\left(\mathrm{ClO}_{4}\right)_{2}\right]$, two perchlorate anions occupy the axial positions of a distorted axially elongated octahedron and four nitrogen atoms occupy the equatorial plane in a trans mode, Figure 35a. For $\left.\left[\mathrm{Cu}(2 \mathrm{Hamb})_{2}(\mathrm{dca})_{2}\right)\right]$ two amide nitrogen atoms of two dicyanamide anions are situated at the axial sites of an axially elongated octahedron. ${ }^{56}$ The nickel(II) complex corresponds to $\left[\mathrm{Ni}(2 \mathrm{Hamb})_{2}(2 \mathrm{amb})\right] \mathrm{N}(\mathrm{CN})_{2} \cdot \mathrm{H}_{2} \mathrm{O}$, where the central metal ion is in a distorted octahedral geometry; with three coordinated ligands in a facial mode. Two of the three 2-aminomethylbenzimidazole (2Hamb) ligands are neutral, while the third one is anionic, Figure $35 b .^{57}$ 


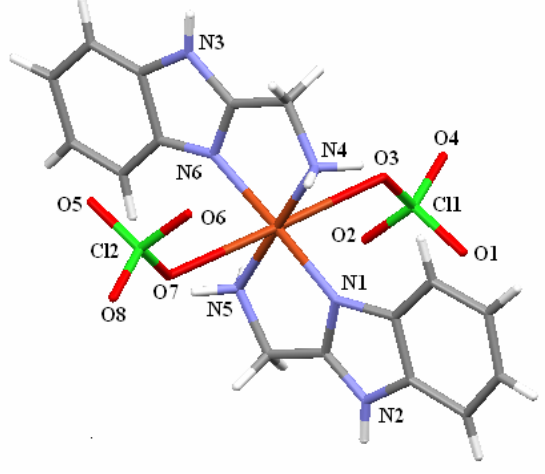

a

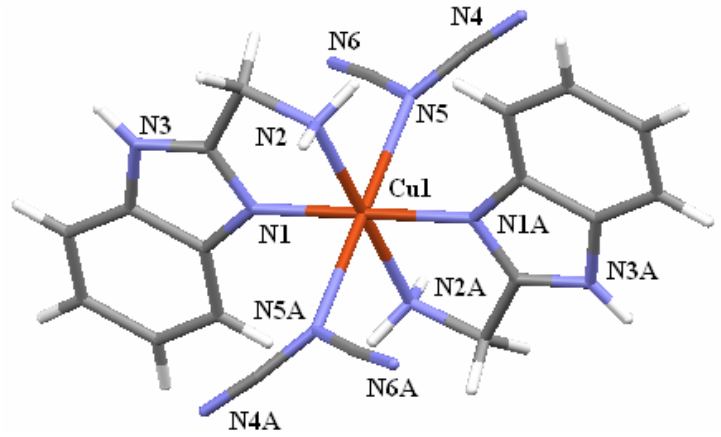

$\mathrm{b}$

Figure 35. (a) $\left[\mathrm{Cu}(\mathrm{Hambi})_{2}\left(\mathrm{ClO}_{4}\right)_{2}\right]$ and (b) $\left[\mathrm{Ni}(\mathrm{Hambi})_{2}(\mathrm{ambi})\right] \mathrm{N}(\mathrm{CN})_{2} \cdot \mathrm{H}_{2} \mathrm{O} .^{56,57}$

3.2.1.6 2-(2-Pyridyl)-benzimidazole. Zhou et al. reported four different copper(II) coordination compounds with 2-(2-pyridyl)benzimidazole and four carboxylates: maleate, crotonate, methacrylate and acrylate that stabilize supramolecular structures. The first compound $\left\{[\mathrm{Cu}(\mathrm{Hpb})(\mathrm{mal})] \cdot \mathrm{H}_{2} \mathrm{O}\right\}_{\mathrm{n}}(1)$, consists of one benzimidazole, coordinated as a bidentate ligand, and two maleate anions, one acting as a chelate through two oxygen atoms, while the other behaves as a bridging ligand also bonding to an adjacent copper atom, the geometry around the metal ion is a distorted square-pyramid. It forms a 1D helical chain polymer producing a 3D network with open channels. With crotonate, a tetranuclear compound $\left[\mathrm{Cu}_{4}(\mathrm{pb})_{4}(\mathrm{cro})_{4}(\mathrm{MeOH})_{2}\right] \cdot 2 \mathrm{MeOH}(2)$ is obtained; here each metal ion presents a square pyramidal geometry. In this case, the deprotonated benzimidazole ligands are coordinated through two nitrogen atoms, as in the previous compound, where two copper(II) ions are bridged by crotonate oxygen atoms forming a rectangular arrangement, while the other two copper(II) ions are linked by bridging oxygen atoms from two crotonate groups and a methanol molecule occupies the apical position of the square pyramid, Figure 36a. The tetranuclear units extend into a 2D sheet with solvent molecules located in the grids. Complex (3), $\left[\mathrm{Cu}_{2}(\mathrm{pb})(\mathrm{Hpb})(\mathrm{mac})_{3}(\mathrm{MeOH})\right]$ Figure 36b, and complex (4), $\left[\mathrm{Cu}(\mathrm{Hpb})(\mathrm{acr})_{2}\left(\mathrm{H}_{2} \mathrm{O}\right)\right]$ generate a 1D sinusoidal chain and a 3D supramolecular network, respectively, through hydrogen bonding and $\pi-\pi$ stacking interactions. In compound $\left[\mathrm{Cu}(\mathrm{Hpb})(\mathrm{acr})_{2}\left(\mathrm{H}_{2} \mathrm{O}\right)\right]$, two monodentate acrylate ligands, a neutral bidentate 2-(2-pyridyl)benzimidazole and a water molecule complete pentacoordination in a distorted square-pyramidal geometry. It is important to mention that these compounds present different magnetic behavior as a consequence of the coordination mode of the carboxylates; syn-anti $\mu$-OCO bridging gives weak ferromagnetic coupling as shown in compound (1), in (2) a syn-syn $\mu$-OCO bridging system results in large antiferromagnetic coupling, while compound (3) is slightly ferromagnetic, due to the presence of syn-syn $\mu-\mathrm{OCO}$ bridging and a monodentate carboxylate. ${ }^{58}$ 


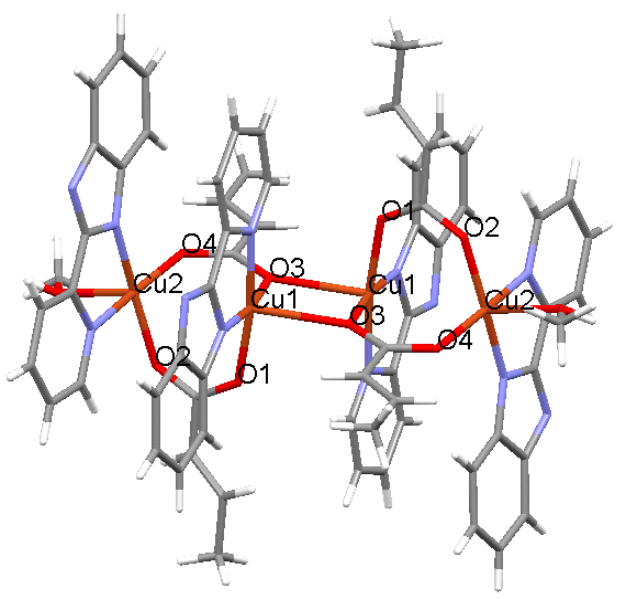

a

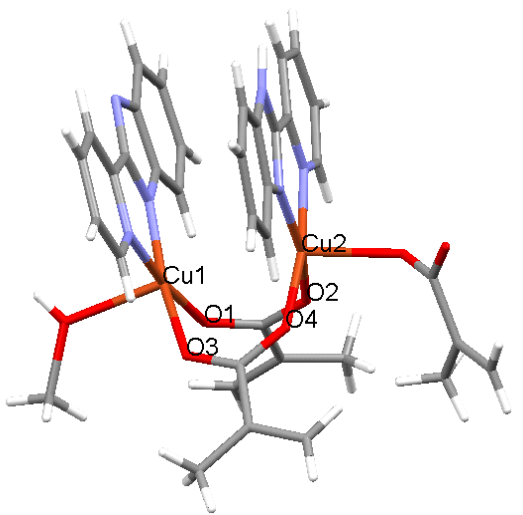

$\mathrm{b}$

Figure 36. (a) $\left[\mathrm{Cu}_{4}(\mathrm{pb})_{4}(\mathrm{cro})_{4}(\mathrm{MeOH})_{2}\right] \cdot 2 \mathrm{MeOH}$ and $(\mathrm{b})\left[\mathrm{Cu}_{2}(\mathrm{pb})(\mathrm{Hpb})(\mathrm{mac})_{3}(\mathrm{MeOH})\right]^{58}$

\subsubsection{2-(2-Benzimidazolyl-6-R)-4,4,5,5-tetramethyl-4,5-dihydro-1H-imidazolyl-3-}

oxide-1-oxy. The structure and magnetic properties of coordination compounds based on benzimidazole substituted nitronyl nitroxide radicals have been studied by Rey et. al., ${ }^{59}$ where the employed ligands, have different substituents on the benzimidazole ring, NITBzImH $(\mathrm{R}=\mathrm{H})$, $\operatorname{NITBzMeImH}(\mathrm{R}=\mathrm{Me})$ and $\mathrm{NITBz}\left(\mathrm{NO}_{2}\right) \operatorname{ImH}\left(\mathrm{R}=\mathrm{NO}_{2}\right)$, as shown in Figure 37.

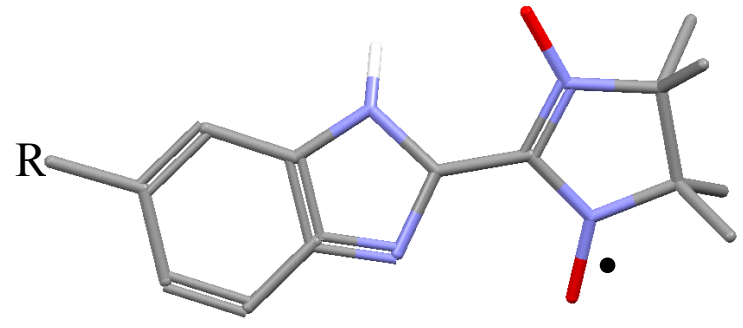

Figure 37. Nitronyl nitroxide radicals NITBzImH $(\mathrm{R}=\mathrm{H})$, NITBzMeImH $(\mathrm{R}=\mathrm{Me})$ and $\operatorname{NITBz}\left(\mathrm{NO}_{2}\right) \operatorname{ImH}\left(\mathrm{R}=\mathrm{NO}_{2}\right) .{ }^{59}$

The mononuclear, one-dimensional, manganese(II) compound mer$\left[\mathrm{Mn}(\mathrm{NITBzImH})_{3}\right]\left(\mathrm{ClO}_{4}\right)_{2} \cdot \mathrm{H}_{2} \mathrm{O}$ presents metal-radical interactions which are antiferromagnetic. While two dimensional manganese(II) laminar compounds $\left\{\left[\mathrm{Mn}_{2}(\mathrm{NITBzRImH})_{3}\right] \mathrm{ClO}_{4}\right\}_{\mathrm{n}}$, show weak ferromagnetism, behaving as spin carriers. 


\subsection{2. $(\mathrm{N}, \mathrm{O})$ coordination compounds}

3.2.2.1 1-(Benzimidazol-2-yl)phenolato. The compound 2-(benzimidazol-2-yl)phenolato (2bph) has been widely used as ligand in new coordination compounds, with transition metal ions; principally towards cobalt(II), copper(II) and zinc(II), see Figure 38. The bis(2(benzimidazol-2-yl)phenolato- $N, O)$-cobalt(II) compound, [Co(2bph $\left.)_{2}\right]$, contains two anionic ligands, which are coordinated through nitrogen and oxygen atoms. ${ }^{60}$ Analogous compounds are obtained, from $\mathrm{Cu}(\mathrm{OAc})_{2} \cdot \mathrm{H}_{2} \mathrm{O}$ and $\mathrm{Zn}(\mathrm{OAc})_{2} \cdot \mathrm{H}_{2} \mathrm{O}$. These complexes have the same molecular structure $\left[\mathrm{M}(2 \mathrm{bph})_{2}\right]_{2} \cdot \mathrm{DMF}{ }^{61,62}$
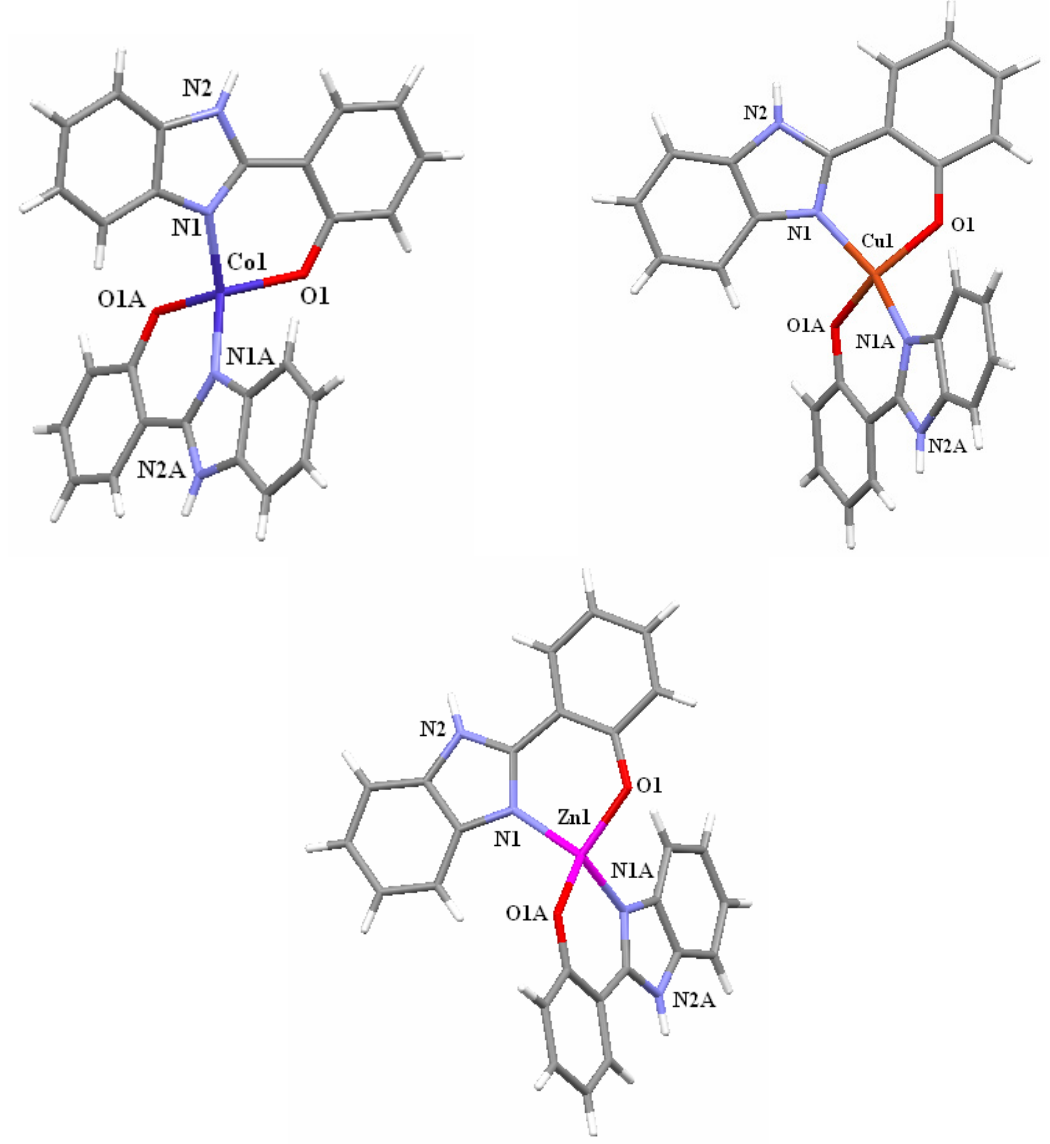

Figure 38. Coordination compounds containing 2-(benzimidazol-2-yl)phenolato (2bph) ${ }^{60-62}$

3.2.2.2 2-(2-Benzimidazol-2-yl)pyridine-N-oxide-N,O. R. Boca et al. reported coordination compounds of 2-(2-benzimidazol-2-yl)pyridine- $N$-oxide- $N, O$ and first row transition metals, of molecular formula $\left[\mathrm{ML}_{2} \mathrm{X}_{2}\right] \cdot \mathrm{nH}_{2} \mathrm{O}$. Octahedral compounds were obtained with cobalt(II) and zinc(II), in each case the ligand coordinates through the oxygen and imine nitrogen atoms of the benzimidazole group and two water molecules complete hexacoordination, see Fig. $39 .{ }^{63}$ 


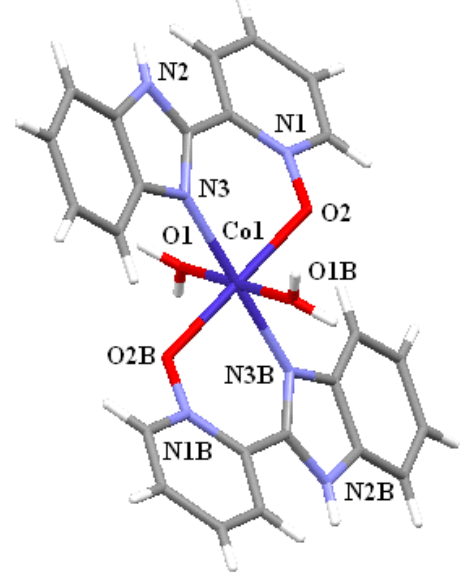

Figure 39. $\mathrm{Co}{ }^{\text {II }}$ compound of 2-(2-benzimidazol-2-yl)pyridine- $N$-oxide- $N, O{ }^{63}$

\subsection{3 (N, S) coordination compounds}

3.2.3.1 - N-(Benzothiazol-2-yl)-dithiocarbamic methyl ester. R. Contreras et al. reported an interesting spirocyclic structure $\left[\mathrm{Co}(\mathrm{btz}-\mathrm{SMe})_{2}\right]$, the ligand is a derivative of benzothiazole, is anionic and behaves as bidentate. Nitrogen and sulfur atoms are bonded to the central metal ion giving planar tricyclic chelates, where cobalt(II) is part of the six-membered rings, Figure $40{ }^{39}$

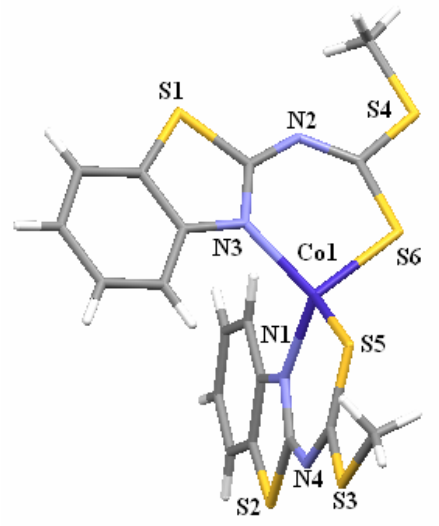

Figure 40. $\left[\mathrm{Co}(\mathrm{btz}-\mathrm{SMe})_{2}\right]{ }^{39}$

\section{Concluding Remarks}

Coordination compounds containing benzazole derivatives and transition metal ions have attracted the interest of several research groups, partly due to their very interesting chemistry as well as their possible applications. It has been shown that 2-benzimidazole derivatives allow coordination towards metal ions through a variety of sites, with groups bearing nitrogen, oxygen 
and sulfur atoms coordination occurs through the imidazolic nitrogen atom and also through $\mathrm{N}, \mathrm{S}$ or $\mathrm{O}$ atoms present in the molecule, giving place to a variety of metal-ligand coordination modes. In some compounds the formation of a six membered ring by inclusion of a metal ion gives place to a planar delocalized system, while for other complexes different stereochemistries, geometries, conformers and tautomers are stabilized.

Benzimidazolic coordination compounds containing carboxylates promote the formation of polymeric compounds (catena) by intra and intermolecular interactions, where benzimidazole plays an important role in the stabilization of the structures through $\pi$-stacking interactions. These types of compounds show diverse magnetic properties.

\section{Ackowledgements}

Financial support from project DGAPA-UNAM, IN206707 is acknowledged. F. T. thanks CONACyT for post-doctoral fellowship.

\section{References}

1. Pawar, N. S.; Dalal, D. S.; Shimpi, S. R.; Mahulikar, P. P. Eur. J. Pharm. Sci. 2004, 21, 115.

2. Ören, İ.; Temiz, Ö.; Yalçin, İ.; Şener, E.; Altanlar, N. Eur. J. Pharm. Sci. 1998, 7, 153.

3. Hisano, T.; Ichikawa, M.; Tsumoto, K.; Tasaki, M. Chem. Pharm. Bull. 1982, 30, 2996.

4. Mothilal, K. K.; Karunakaran, C.; Rajendran, A.; Murugesan, R. J. Inorg. Biochem. 2004, $98,322$.

5. Özden, S.; Atabey, D.; Yildiz, S.; Göker, H. Bioorg. Med. Chem. 2005, 13, 1587.

6. He, Y.; Wu, B.; Yang, J.; Robinson, D.; Risen, L.; Ranken, R.; Blyn, L.; Sheng, S.; Swayze, E. E. Bioorg. Med. Chem. Lett. 2003, 13, 3253.

7. Kazimierrczuk, Z.; Upcroft, J. A.; Upcroft, P.; Górska, A.; Starościak, B.; Laudy, A. Acta Biochim. Polonica 2002, 49, 185.

8. Kühler, T. C.; Swanson, M.; Christenson, B.; Klintenberg, A. C.; Lamm, B.; Fägherhag, J.; Gatti, R.; Ölwegård-Halvarsson, M.; Shcherbuchin, V.; Elebring, T.; Sjöström, J. J. Med. Chem. 2002, 45, 4282.

9. Carcanague, D.; Shue, Y.; Wuonola, M.; Uria-Nickelsen, M.; Joubran, C.; Abedi, J. K.; Jones, J.; Kühler, T. C. J. Med. Chem. 2002, 45, 4300.

10. Klimešová, V.; Kočí, J.; Pour, M.; Stachel, J.; Waisser, K.; Kaustová, J. Eur. J. Med. Chem. 2002, 37, 409.

11. Küçükbay, H.; Durmaz, R.; Güven, M.; Günal, S. Arzneim Forsch Drug Res. 2001, 51, 420.

12. Lukevics, E.; Arsenyan, P.; Shestakova, I.; Domracheva, I.; Nesterova, A.; Pudova, O. Eur. J. Med. Chem. 2001, 36, 507. 
13. (a) Valdez-Garay, J.; Cedillo, R.; Hernández-Campos, A.; Yepez, L.; Hernández-Luis. F.; Navarrete-Vázquez, G.; Tapia, A.; Cortés, R.; Hernández, M.; Castillo, R. Bioorg. Med. Chem. Lett. 2002, 12, 2221. (b) Ayhan-Kilcigil, G.; Altanlar, N. Turk. J. Chem. 2006, 30, 223.

14. Devereux, M.; McCann, M.; Shea, D. O.; Kelly, R.; Egan, D.; Deegan, C.; Kavanagh, K.; McKee, V.; Finn, G. J. Inorg. Biochem. 2004, 98, 1023.

15. Tavman, A.; Ülküseven, B.; Birteksöz, S.; Ötük, G. Folia Microbiol. 2003, 48, 479.

16. Ülküseven, B.; Tavman, A.; Ötük, G.; Birteksöz, S. Folia Microbiol. 2002, 47, 481.

17. Ülküseven, B.; Tavman, A.; Ötük, G. Metal-Based Drugs 1999, 6, 163.

18. (a) Yoe-Reyes, F.-J.; Bernes, S.; Barba-Behrens, N. Acta Crystallogr. 2005, E61, m875. (b) Şahin, E.; Ide, S.; Kurt, M., Yurdakul, Ş. J. Mol. Struct. 2002, 616, 259. (c) Şahin, E.; Ide, S.; Kurt, M.; Yurdakul, Ş. Z. Kristallogr. 2003, 218, 385.

19. Bukowska-Strzyzewska, M.; Tosik, A. J. Crystallogr. Spectrosc. Res. 1991, 21, 379.

20. a) Tosik, A.; Bukowska-Strzyzewska, M. J. Chem. Cryst. 1994, 24, 139. b) Tosik, A.; Maniukiewicz, W.; Bukowska-Strzyzewska; Mrozinski, J.; Sigalas, M. P; Tsipis, C. A. Inorg. Chimica Acta 1991, 190, 193.

21. (a) Tosik, A.; Bukowska-Strzyzewska, M.; Mrozinski, J. J. Coord. Chem. 1991, 24, 113. (b) Zhang, Y. Q.; Xu, D.-J.; Su, J. R. Acta Crystallogr. 2003, E59, m919.

22. Cruz-Núñez M. E., B.Sc. Thesis, Universidad Nacional Autónoma de México, 2007.

23. (a) Lin, D.-D.; Liu, Y.; Xu, D.-J. Acta Crystallogr. 2003, E59, m771. (b) Xue, Y.-H., Lin, D.-D.; Xu, D.-J. Acta Crystallogr. 2003, E59, m750. (c) Tosik, A.; Sieron, L.; BukowskaStrzyzewska, M. Acta Crystallogr., Sect. C: Cryst. Struct. Commun. 1995, 51, 1987.

24. (a) Xue Y.-H.; Xu, D.-J.; Gu, J.-M. Acta Crystallogr. 2003, E59, m387. (b) Xue, Y.-H.; Liu J.-G.; Xu, D.-J. J. Coord.Chem. 2005, 58, 1071.

25. (a) Liu, Y.; Xu, D.-J.; Lin, D.-D.; Yin, K.-L. Acta Crystallogr. 2003, E59, m753. (b) Liu, Y.; Xu, D.-J. Acta Crystallogr. 2004, E60, m1002. (c) Sieron, L.; Bukowska-Strzyzewska, M. Acta Crystallogr., Sect. C: Cryst. Struct. Commun. 1998, 54, 1431. (d) Xue, Y.-H.; Liu, Y.; Xu, D.-J. Acta Crystallogr. 2003, E59, m944.

26. (a) Pan, T.-T.; Su, J.-R.; Xu D.-J. Acta Crystallogr. 2005, E61, m1928. (b) Su, J.-R.; Liu, Y.; Xu, D.-J. Acta Crystallogr. 2004, E60, m1298.

27. Liu, Y.; Xu, D.-J. Acta Crystallogr. 2004, E60, m1092.

28. (a) Li, H.; Yin, K.-L.; Xu, D.-J. Acta Crystallogr., Sect. C: Cryst. Struct. Commun. 2005, 61, m19. (b) Su, J.-R.; Xu, D.-J. J. Coord. Chem. 2005, 58, 629. (c) Su, J.-R.; Gu, J.-M.; Xu, D.J. Acta Crystallogr. 2005, E61, m244. (d) Huang, X.; Xiao. L.-P.; Xu, D.-J. Acta Crystallogr. 2006, E62, m2246.

29. (a) Tosik, A.; Sieron, A. L.; Bukowska-Strzyzewska, M. Acta Crystallogr., Sect. C: Cryst. Struct. Commun. 1995, 51, 1985. (b) Sieron, A. L.; Bukowska-Strzyzewska, M.; Korabik, M.; Mrozinski, J. Polyhedron 2002, 21, 2473. (c) Sieron, A. L.; Bukowska-Strzyzewska, M. Acta Crystallogr., Sect. C: Cryst. Struct. Commun. 1999, 55, 1230. 
30. Van Albada, G. A.; Reedijk, J.; Haasnoot, J. G.; Biagini-Cingi, M.; Manotti-Lanfredi, A. M.; Ugozzoli, F. Polyhedron 1995, 14, 2467.

31. Gao, S.; Gu, C.-S.; Huo, L.-H.; Liu, J.-W.; Zhao, J.-G. Acta Crystallogr. 2004, E60, m1936.

32. (a) Hu, M.-L.; Zhu, N.-W.; Xiao, H.-P. Acta Crystallogr. 2005, E61, m898. (b) Hu, M.-L.; Wang, W.-D. Acta Crystallogr. 2005, E61, m975.

33. (a) Bukowska-Strzyzewska, M.; Skoweranda, J.; Tosik, A. Acta Crystallogr., Sect. B: Struct. Crystallogr. Cryst. Chem. 1982, 38, 2904. (b) Wang, Y.; Shi, Q.; Yang, B.; Shi, Q.; Gao, Y.; Zhou, Z. Sci. China, Ser. B 1999, 42, 363.

34. Gao, S.; Liu, J.-W.; Huo, L.-H.; Zhao, H. Chinese J. Struct. Chem. 2005, 24, 789.

35. (a) Cao, L.; Xu, D.-J. Acta Crystallogr. 2005, E61, m2127. (b) Zhang, L.; Dai, Z.-Y. Chinese J. Struct. Chem. 2004, 23, 386.

36. (a) Roman-Alpiste, M. J.; Martin-Ramos, J. D.; Castineiras-Campos, A.; BugellaAltamirano, E.; Sicilia-Zafra, A. G.; Gonzalez-Perez, J. M.; Niclos-Gutierrez, J. Polyhedron 1999, 18, 3341. (b) Su, J.-R.; Yin, K.-L.; Xu, D.-J. Acta Crystallogr. 2004, E60, m1020. (c) Su, J.-R.; Xu, D.-J. J. Coord. Chem. 2004, 57, 223.

37. (a) Fialon, M.-P.; García Baéz, E.; Andrade-López, N.; Osorio-Monreal, G.; CansecoMelchor, G.; Velázquez-Montes, I.; Barba-Behrens, N.; Contreras, R. Heteroatom Chem. 1999, 10, 577. (b) Sánchez-Guadarrama O., MSc. Thesis, Universidad Nacional Autónoma de México, 2007.

38. Téllez, F.; Cruz, A.; López-Sandoval, H.; Ramos-García, I.; Gayosso, M.; Castillo-Sierra, R. N.; Paz-Michel, B.; Nöth, N.; Flores-Parra, A.; Contreras, R. Eur. J. Org. Chem. 2004, 4203.

39. Téllez, F.; Barba-Behrens, N.; Flores-Parra, A.; Contreras, R. Polyhedron 2004, 22, 2481.

40. Téllez, F.; Peña-Hueso, J. A.; Barba-Behrens, N.; Flores-Parra, A.; Contreras, R. Polyhedron 2006, 25, 2363.

41. Grevy, J M. Téllez, F.; Bernès, S.; Nöth, H.; Contreras, R.; Barba-Behrens, N. Inorg. Chimica Acta 2002, 339, 532.

42. Devereux, M.; McCann, M.; Shea, D. O.; Kelly, R.; Egan, D.; Deegan, C.; Kavanagh, K.; McKee, V.; Finn, G. J. Inorg. Biochem. 2004, 98, 1023.

43. Sethuraman, V.; Stanley, N.; Muthiah, P. T.; Karunakaran, C. Acta Crystallogr. 2002, E58, m392.

44. Sbai, F.; Regragui, R.; Essassi, E.; Kenz, A.; Pierrot, M. Acta Crystallogr. Sect. C: Cryst. Struct. Commun. 2003, 59, m334.

45. Sbai, F.; Regragui, R.; Essassi, E.; Kenz, A.; Pierrot, M. Acta Crystallogr. 2003, E59, m571.

46. Sbai, F.; Chkirate, K.; Regragui, R.; Essassi, E. M.; Pierrot, M. Acta Crystallogr. 2002, E58, $\mathrm{m} 337$.

47. Hernández-García, R. M.; Barba-Behrens, N.; Salcedo, R.; Höjer, G. J. Mol. Struct (THEOCHEM) 2003, 637, 55.

48. Barba-Behrens, N.; Vázquez-Olmos, A.; Castillo-Blum, S. E.; Höjer, G.; Meza-Höjer, S.; Hernández, R. M.; Rosales-Hoz, M. de J.; Vicente, R.; Escuer, A. Trans. Met. Chem. 1996, 21,31 . 
49. Hernández-García, R. M.; Ph. D. Thesis, Universidad Nacional Autónoma de México, 2007.

50. (a) Van Albada, G. A.; Mutikainen, I.; Turpeinen, U.; Reedjijk, J. J. Mol. Struct. 2006, 789, 182. (b). Arablo, N.; Torabi, S. A. A.; Morsali, A.; Skelton, B. W.; White, A. H. Aust. J. Chem. 2003, 56, 945.

51. Andrade-López, N.; Ariza-Castolo, A.; Vázquez-Olmos, A.; Tlahuext, H.; Barba-Behrens, N.; Contreras, R. Heteroatom Chem. 1997, 8, 397.

52. Ceniceros-Gómez, A.; King-Díaz, B.; Barba-Behrens, N.; Lotina-Hennsen, B.; CastilloBlum, S. E. J. Agric. Food. Chem. 1999, 47, 3075.

53. Sykes, A. G. Chem. Soc. Rev. 1985, 283.

54. Ceniceros-Gómez, A.; Barba-Behrens, N.; Bernés, S.; Nöth, H.; Castillo-Blum, S. E. Inorg. Chimica Acta 2000, 304, 230.

55. Ceniceros-Gómez, A.; Barba-Behrens, N.; Quiroz-Castro, M. E.; Bernes, S.; Nöth, H.; Castillo-Blum, S. E. Polyhedron 2000, $19,1821$.

56. He, Y.; Kou, H.-Z.; Wang, R.-J.; Li, Y.; Xiong, M. Transition Met. Chem. 2003, $28,464$.

57. He, Y.; Kou, H. Z.; Zhou, B. C.; Xiong, M.; Wang, R.-J.; Li Y. Acta Crystallogr. 2002, E58, m389.

58. Zhou, L. J.; Luan, X. J.; Wang, Y. Y.; Lee, G. H.; Shi, Q. Z.; Peng, S. M. J. Coord. Chem. 2006, 59, 1107.

59. Luneau, D., Rey, P. Coord. Chem. Rev. 2005, 249, 2591.

60. Bu, H.-Y.; Liu, Y.-J.; Liu, Q.-F.; Jia, J.-F. Acta Crystallogr. 2005, E61, m1986.

61. Xi, Y.; Li, J.; Zhang, F. Acta Crystallogr. 2005, E61, m1953.

62. Zhao, Y.-H.; Su, Z.-M.; Wang, Y.; Hao, X.-R.; Shao, K.-Z. Acta Crystallogr. 2006, E62, $\mathrm{m} 2361$.

63. Vrbova, M.; Baran, P.; Boca, R.; Fuess, H.; Svoboda, I.; Linert, W.; Schubert, U.; Wiede, P. Polyhedron 2000, 19, 2195. 